\title{
Introduction to Tourism Satellite Accounts
}

\author{
Tadayuki (Tad) Hara \\ ${ }^{1}$ Rosen College of Hospitality Management, University of Central Florida \\ $\mathcal{E}$ Advisory Committee Member on International Trends on Tourism Statistics, \\ 2Japan Tourism Agency, Ministry of Land, Infrastructure, Transport and Tourism \\ ${ }^{1}$ USA \\ 2Japan
}

\section{Introduction}

While tourism appear to be a fun topic to study in general, tourism is tough to measure as an industry. Tourism emerged as a viable industry a little bit too late to be included in the system of national accounts. Therefore, we have to work around the established national accounting systems to measure it as accurate as possible, while tourism researchers must pay respect to the existing accounting system of the world. Tourism Satellite Accounts (TSA) is a de-jure measure to record activities of tourism as an industry, and it should be emphasized that TSA is not a modelling but accounting to record annual activities of tourism as an industry, similar to income statement (profit and loss statement). In that regard, any attempts by academics to simulate the TSA is just a wrong notion in light of the fundamental spirit of TSA.

Without a technique such as TSA, we can still make an attempt to guess how large the tourism industry is. We may pick up industrial sectors which appear to have strong association with tourists, such as hotels and airlines as a representative group of tourism industry. But if you pick up only highly visible industrial sector that cater to tourists, you have a risk of underestimating the true size of the tourism as an industry. Tourists have to eat, move around (by renting a car or using public transportations), buy souvenirs, purchase attractions and theme park tickets etc. We may widen the selection of industrial sectors beyond hotels and airlines and attribute all the sales of those industrial sectors to tourists' expenditure. Is it reasonable for us to assume that all the sales at coffee shops in a large shopping centers in Tripoli, Dublin, Helsinki, Osaka, Seoul, and Yelevan can be attributed to expenditures by tourists only, even though some of the shopping centers may look like the case? While some sports clubs in resort setting look like they cater only to tourists, how about sports clubs in Kiev, Kyoto or Prague? If there are clients other than tourists, who are they and how should we treat their expenditures to sports club? Unless you introduce certain criteria and rules, inclusion of all the revenues at tourists-affiliated industrial sectors would end up over-estimating the true size of the tourism as an industry. It appears that we have to formulate a concept of a group of industrial sectors which cater to tourists, almost an idea of an industrial complex and extract only the portion of sales which are attributable to tourists, to analyze tourism as an industry. 
TSA requires you to filter out the outputs of each industrial sectors into those for tourists and those for others (non-tourists) at the demand side ("who consumed it") and combine those outputs consumed by tourists (visitors) as a mean to assemble them as an industry. TSA has blessings of notable international organizations, including but not limited to World Bank, IMF, OECD, United Nations and its UNWTO as well as tens of nations in the world, which budgets hundreds of millions of dollars of taxpayers' money and engage top economists and national statistics experts to compile, while tourism and hospitality researchers and students sadly have little clue due to apparent disconnect between the world and academics. One of the reasons for disconnect would be the fact that structure of TSA is based on I-O, which appear to present a huge hurdle for many tourism researchers. That is the reason for this chapter to explain minimum required knowledge so that you understand how TSA is created, instead of just talking about it.

\section{Brief history}

According to Organisation for Economic Cooperation and Development (OECD), around $30 \%$ of international trade in services in the OECD zone can be attributed to tourism and that travel part of the service sector of OECD nations, which now count 30 nations, generate around $70 \%$ of world-wide tourism business. (OECD 2000) In response to surge of relative importance of tourism as an industry in the last part of the 20th century, national and international organizations proposed methods to capture tourism as an industry. It was not until 1991 that Statistics Canada, Canada's national statistical agency, presented a proposal on TSA at Ottawa Conference on Tourism, followed by presentation of its first results in 1994.

The Commission of the European Communities, the International Monetary Fund, the Organisation for Economic Co-operation and Development, United Nations and the World Bank jointly published the 1993 System of National Accounts to update various issues of measurement of market economies in the world from previous versions in 1953 and 1968. Section B, 1. Production and Products in chapter XXI SATELLITE ANALYSIS AND ACCOUNTS, mentions about issues of measuring tourism. In 1995 World Tourism Organization (UNWTO) started to put proposals on TSA, and in 2000 OECD published a manual called "Measuring the Role of Tourism in OECD Economies".

(Contents of the 1993 System of National Accounts are available at the web page of United Nations Statistics Division: http://unstats.un.org/unsd/sna1993/introduction.asp)

Based on the latest global survey made by Tourism Statistics and Tourism Satellite Accounts Division of the World Tourism Organization (UNWTO), as of June 2010, 60 nations in the world have been identified to have national level TSA. List of those nations with TSA can be seen in page 2 of the following material.

http://statistics.unwto.org/sites/all/files/pdf/tsa_data.pdf

Recently, the leadership of TSA advancement has been exercised by the Tourism Statistics and Tourism Satellite Accounts Division of the UNWTO. What is very important here is that TSA is a de jure method to measure tourism as an industry, and not just one of the several methods advocated by different people. This is the only official method for everybody in the world to measure tourism as an industry. Having said that, I assume you would be surprised that majority of tourism educational programs do not teach this subject to their 
students, mainly because of the lack of knowledge of both instructors and students on how TSA works. Therefore, we have this chapter.

\section{Some key concepts of TSA}

\subsection{Simple basic concept of TSA}

\subsubsection{The rationale for "Satellite"}

Why TSA includes the word "Satellite" which is the object in orbit to circle around the earth? It would not require knowledge of rocket science to understand it. As we learned in Input-Output transactions table, we have certain established industrial sectors already based on their products. Those framework was developed in 1930 and 1940's using the framework of Input-Output, and those sectors included Agriculture, Mining, Construction, Manufacturing, Trade, Finance/Insurance/Real Estate, Services, and Government. Those framework later became universal standard in the form of System of National Accounts (SNA), which, as you see, was built on the framework of Input-Output. SNA has been providing universal standard to measure economic activities of nations in the world, such as Gross Domestic Product (GDP), thus it is now established as an earth. So TSA moves around the earth (established SNA) to find out where the tourism industry is hidden in the earth, with the purpose of extracting tourism industry out of the existing industrial sectors and combine them as a quasi-industry.

In other words, tourism as an industry came out too late to be included in the established system of National Accounts. Therefore, researchers have to look around the existing industrial sectors and identify how much of tourism-related consumptions are hidden in the sales of each existing industrial sectors, to make the best measurement of aggregated amount of tourism-related activities in the whole industry. As the real satellites do, the mission of TSA is to observe the object as precise as possible, just like the concept of Accounting. It is important for us to note that TSA is an Accounting, and not modelling of simulations, which is sometimes misunderstood by some researchers.

The image of TSA concept can be shown as Figure 1.

\subsection{Basic important definitions used in TSA}

In order to capture fuzzy subjects of tourism into measurable framework, TSA has several key definitions with which tourism as an industry will be distinguished from the rest of the economic activities. Here are some of the key concepts that would be helpful for us to follow the TSA logics.

\subsubsection{Visitor and tourist}

While a word "tourist" gives us the impression of leisure travellers, there are non-leisure travellers, such as company employees who travel to meet their customers, or non-leisure personal travellers such as visiting grandparents in their hometown. A word "visitor" will include those travellers. So, the important idea for differentiation would be not whether a person would be a tourist or a non-tourist, but whether a person would be a visitor or a nonvisitor. 


\section{Image of TSA Concept}

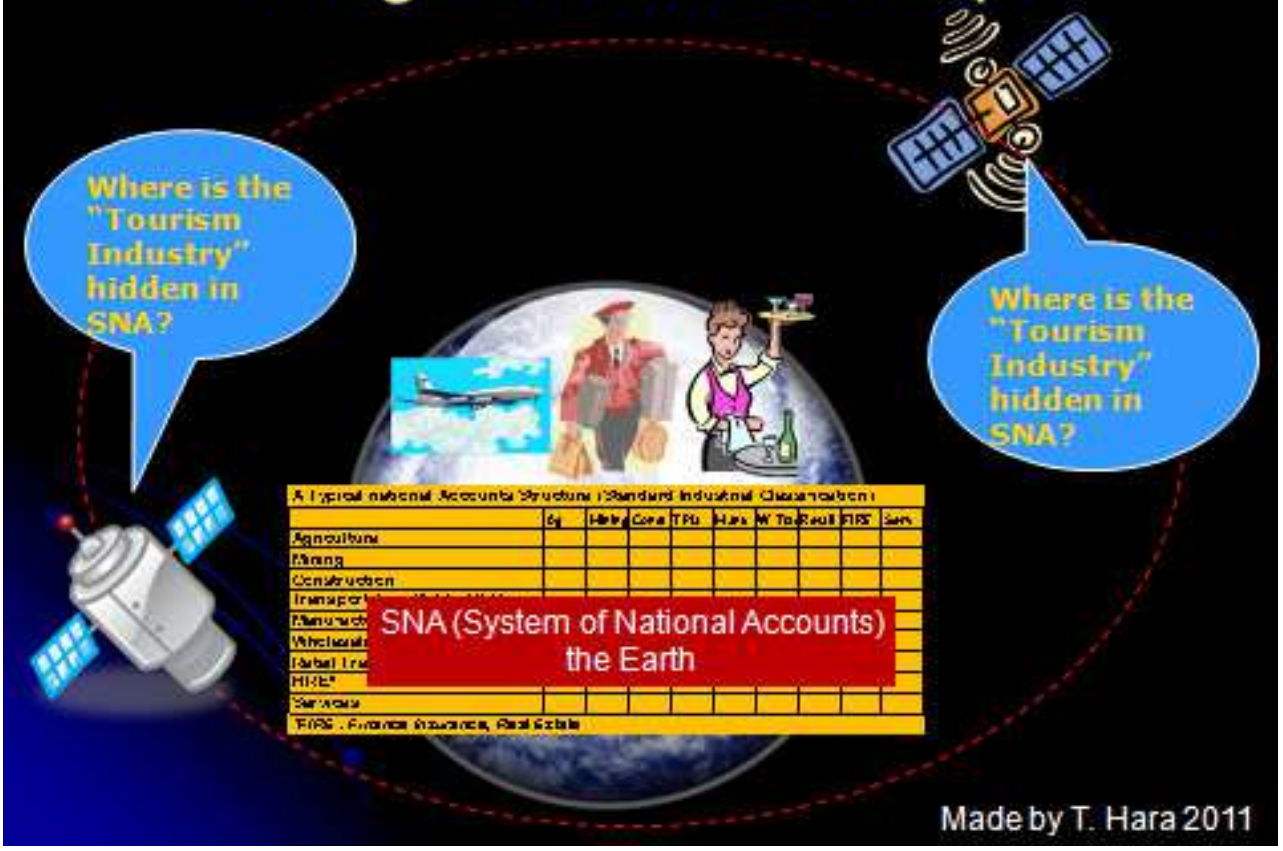

Fig. 1. Image of TSA Concept

\subsubsection{Usual and unusual environment}

To illustrate points in question, here are several questions for you. If you visit an Olympics game in United Kingdom from Spain, you are most likely classified as visitors. Here are some more questions;

- If you visit a Hilton hotel 20 miles $(32 \mathrm{~km})$ from your house, are you considered as a visitor?

- Many of those who live in Tokyo, Japan enjoy their occasional visits to the Tokyo Disneyland, which is located in Chiba prefecture but only about 10 miles $(16 \mathrm{~km})$ away from the central part of Tokyo. Are Tokyoites considered as leisure visitors when they visit Tokyo Disneyland?

- If a Australian manager went to Bilbao, Spain and stayed there for a two weeks to close a business deal, is she considered as a visitor?

- If a Ukrainian student came to the U.S to study English for 6 months, but thanks to his hard work, obtained good English scores in TOEFL and switched status as full time graduate student to stay 2 years, is he still a visitor?

There can be one simple method to decide whether a person in question can be considered as "a visitor". One of the possible methods would be "distance" to be used as a cut-off line, with those who travel above certain distance to be considered visitors, and those who did not 
travel over the distance not to be considered visitors. We have a minor problem, however, that there is no universal agreement on the distance. In the U.S., the Consumer Expenditure Survey by Bureau of Labor Statistics, the American Travel Survey by Bureau of Transportation Services use difference distance (75 miles and 100 miles respectively), and indeed the distance criteria for visitors is different from one nation to the other. If you insist on imposing one of the most accepted universal distance such as 50 miles $(80 \mathrm{~km})$, then for a nation like Bahrain in the Arabian Gulf or Singapore in Southeast Asia, or Aruba in the Caribbean, there would be almost nobody ever to be classified as domestic tourists (= leisure visitors) at all.

This discussion on usage of certain distances to distinguish usual and unusual environment is one example of the fact that some parts of TSA are still evolving, and that more feedback from various sources should be a welcome addition to improve the concept. This is another reason why hospitality and tourism students like you should study and contribute to the advances of TSA, as majority of the existing advancements have been made by contributions from economists who may have less exposure and experience to the operations of hospitality businesses than you do.

\subsection{Supply-based concept and demand-based concept}

In the Input-Output environment, we look at the products, or Output from each industrial sector to classify the group of industrial sectors. You have no difficulty in identifying an peach as an output of the agriculture sector, and broccoli from the same sector. Strawberries, Blueberries and Blackberries (not the phone but fruit) and dates share common characteristics for us to say that they are from agriculture sectors. Characteristics of outputs that industry produces can usually tell us the specific industrial sector.

\subsubsection{Supply-based concept}

In the process above, we did not care who purchased those bananas or water melons. Peaches are peaches irrespective of buyers' characteristics, such as whether the buyer was Households, Governments, Firms or they purchased peaches for final consumption or for intermediate goods to produce peach jam. In order to attribute a product to the producing industry, we look at the output. As we learned in the I-O concept, Production Activities produce outputs to be supplied either to other industrial sectors as intermediate goods or to Households for our final demand. If you look at only the product characteristics to classify the industry, it can be considered as supply-based concept that you use to classify it. If you see a laptop computer, that is the product of manufacturing sector. It did not affect your opinion that the laptop computer was the product from manufacturing sector, whether the buyer was the government (immigration office), firms (private company) or Household (hobbyist).

\subsubsection{Unique characteristics of tourism products}

Now, let's look at an example of tourists. After Nicole and her family travel from Europe to New York, USA, they go through immigration. Then they exchange his Euro into U.S. dollar (banking sector) buy a local map and a bottle of water (retail sector), picks up a taxi (transportation sector) to a hotel. After checking in, they walk around the area and purchased some souvenirs and snacks for children (retail sector). After some relaxation at the hotel, they walked to the movie theatre across the block and purchased entrance tickets (entertainment 
sector). Then they went to a restaurant recommended by the concierge of the hotel, and despite waiting in line for 30 minutes, enjoyed wonderful steak (restaurant sector).

Let's look at more details in what Nicole's family purchased in New York. All the goods and services that they purchased were mostly from the Services sector, but can you tell by the characteristics of the product which products can be easily distinguished as "tourism products"? Banking services can be purchased not only by visitors (leisure visitors = tourists, and non-leisure visitors = non-tourists) but also by non-visitors who live and work in New York, which is one of the thriving large metropolitan cities in the Unites States. Retail shops, such as Seven-Eleven, can be used by both visitors and non-visitors. As you can see, not only visitors but also local residents would take taxis. Souvenirs and snack may be purchased by both visitors and non-visitors, and the same applies to entertainment products. Last example was the consumption at restaurant. While tourists such as Nicole's family can surely come to spend good amount of money at restaurants, also non-visitors come to enjoy the food. So the supply-based product characteristics will not work well to define tourism. Indeed, the concept of tourism is demand-based.

\subsubsection{Demand-based concept of tourism}

When we think about tourism, we have to look at demand-side. This is a very unique point of extracting tourism-related consumption from all the consumption. We will build up tourism-related economic activities by looking at who purchased the product, and decide whether such purchase was caused by a visitor. We cannot assert that all the revenues at the Steak restaurant were caused by visitors only, because tourists love to come to the place. Indeed, the identical Steak dishes may be consumed by tourists at one table and by nonvisitors (local residents) at the next table. We will look into the basic structure of TSA tables.

\section{Compositions tourism satellite accounts}

While detailed logics and explanations are shown in the comprehensive OECD manual (OECD 2000), it showed detailed suggested tables for TSA without actual numbers.

In general, TSA study would include, but not limited to, the following concepts and discussions.

1. Definitions of visitors, usual environment

2. Definition of Tourism Demand

3. Meaning of Tourism Industries and Tourism Commodities

4. Reviewing the examples of Tourism Commodities and the producers

5. Defining names of Tourism Industries and Corresponding Tourism Commodities

6. Production Table (Make Table) of Tourism Commodities and identification of the Producers of those Tourism Commodities

7. Supplies and Consumptions of Tourism Commodities and All Other Commodities

8. Decomposition of Total Demand for All Commodities into Tourism Demand for Tourism Commodities, then Further Decomposition of Tourism Demand into different type of Visitors for Various Commodities

9. Tourism Output, Intermediate Needs and Value Added

10. Tourism Employment and Compensation 
"Measuring the Role of Tourism in OECD Economies - OECD Manual on Tourism Satellite Accounts and Employment" 2000 shows their recommendation of 22 tables (including 13 types of table with sub-categories) whose titles are shown in Table 1.

\begin{tabular}{|c|c|c|}
\hline \# & Table & Table Name \\
\hline 1 & 1 & Production account of characteristic tourism industries: net basis \& gross basis - current prices \\
\hline 2 & 2 & $\begin{array}{l}\text { Tourism supply and demand by type of commodity and by type of visitor: net basis at purchaser's } \\
\text { price - current prices }\end{array}$ \\
\hline 3 & $2 \mathrm{~A}$ & $\begin{array}{l}\text { Tourism supply and demand by type of commodity and by type of visitor: gross basis at purchaser's } \\
\text { price - current prices }\end{array}$ \\
\hline 4 & 3 & $\begin{array}{l}\text { Supply by characteristic tourism and other industries to meet tourism demand by different types of } \\
\text { visitors: net basis - current prices }\end{array}$ \\
\hline 5 & $3 \mathrm{~A}$ & $\begin{array}{l}\text { Supply by characteristic tourism and other industries to meet tourism demand by different types of } \\
\text { visitors: gross basis - current prices }\end{array}$ \\
\hline 6 & 4 & Tourism value added of characteristic industries and other industries: net basis \\
\hline 7 & 4A & Tourism value added of characteristic industries and other industries: gross basis \\
\hline 8 & 5 & Tourism employment of characteristic industries and other industries \\
\hline 9 & 6 & Visitors' characteristics (same day visitors and tourists - recorded on a net basis for tour operators) \\
\hline 10 & $6 \mathrm{~A}$ & Visitors' characteristics (same day visitors and tourists - recorded on a gross basis for tour operators) \\
\hline 11 & 7 & Characteristic tourism industries' gross capital acquisition - at current prices \\
\hline 12 & 8 & Characteristic tourism industries' gross capital stock - at current prices, end of period \\
\hline 13 & 9 & Production account of characteristic tourism industries: net basis - at prices of previous period \\
\hline 14 & 9A & Production account of characteristic tourism industries: gross basis - at prices of previous period \\
\hline 15 & 10 & $\begin{array}{l}\text { Tourism supply and demand by type of commodity and by type of visitor: net basis at purchaser's } \\
\text { prices - at prices of previous period }\end{array}$ \\
\hline 16 & $10 \mathrm{~A}$ & $\begin{array}{l}\text { Tourism supply and demand by type of commodity and by type of visitor: gross basis at purchaser's } \\
\text { prices - at prices of previous period }\end{array}$ \\
\hline 17 & 11 & $\begin{array}{l}\text { Supply by characteristic tourism and other industries to meet tourism demand by different types of } \\
\text { visitors: net basis - at prices of previous period }\end{array}$ \\
\hline 18 & $11 \mathrm{~A}$ & $\begin{array}{l}\text { Supply by characteristic tourism and other industries to meet tourism demand by different types of } \\
\text { visitors: gross basis - at prices of previous period }\end{array}$ \\
\hline 19 & 12 & $\begin{array}{l}\text { Tourism value added of characteristic industries and other industries: net basis - at prices of previous } \\
\text { period }\end{array}$ \\
\hline 20 & $12 \mathrm{~A}$ & $\begin{array}{l}\text { Tourism value added of characteristic industries and other industries: gross basis - at prices of } \\
\text { previous period }\end{array}$ \\
\hline 21 & 13 & Characteristic tourism industries' gross capital acquisition \\
\hline 22 & 14 & Characteristic tourism industries' gross capital stock \\
\hline
\end{tabular}

Source: compiled by the author from "Measuing the Role of Tourism in OECD Economies - The OECD Manual on Tourism Satellite Accounts and Employment, OECD 2000 P59-85

Table 1. List of Tables in Tourism Satellite Accounts Recommended by Organisation for Economic Cooperation and Development Manual in 2000

These tables are more like manual and official guidance of formats for economists who have knowledge on System of National Accounts. In the classroom setting, however, hospitality and tourism students found rather difficult to maintain their attention to follow the logics of subsequent TSA tables without seeing the actual numbers. Due to the limitations of space in this chapter, I will quote some of the important tables with actual TSA data of the United States of America.

\section{Tourism satellite accounts case studies}

In the first section, we will review all the processes of how the Tourism Satellite Accounts are created by following one of the best and freely available technical papers available 
today. Even though the absolute data may appear outdated, the structures and explanations are clear and remain valid to stand the passage of time. The sequences of explanations are in line with those presented by Hara (2008).

\subsection{TSA at Unites States' federal level}

In the United States, Bureau of Economic Analysis (BEA), Department of Commerce's team developed series of papers on TSA, including the one called "U.S. Travel and Tourism Satellite Accounts for 1992" by S. Okubo and M. Planting, P8-22, Survey of Current Business July 1998, Bureau of Economic Analysis, U.S. Department of Commerce. Teams at BEA already published several updates after the original paper by Okubo and Planting, but the basic framework and sequences of the presentation are still along those presented in the first work. With prior permission of the Dr. Sumiye Okubo, we will look at how respective tables are created one by one, so that we will understand the logics and contents of typical TSA presentations with real numbers. Please note that responsibilities for comments and opinions belong to me, and may not necessarily reflects exactly those of the Dr. Okubo and Mr. Planting.

In the Unites States, TSA is called Travel and Tourism Satellite Accounts (TTSA), which is the same in substance as TSA. The report starts with summary of the whole study and shows the results of the measurement of size and impact of the tourism activities in the United States.

\subsubsection{Summary display}

Their table 1 is the display of summary results, which, in terms of sequence, is something that you will typically create at the end of the all other work. This is a table which appears as an abstract.

\begin{tabular}{|c|c|c|c|c|c|c|}
\hline & \multirow{3}{*}{$\begin{array}{l}\text { Demand } \\
\text { (billions of } \\
\text { dollars) }\end{array}$} & \multirow{3}{*}{$\begin{array}{l}\text { Value } \\
\text { added } \\
\text { (billions of } \\
\text { dollars) }\end{array}$} & \multirow{3}{*}{$\begin{array}{l}\text { Employment } \\
\text { (thousands) }\end{array}$} & \multicolumn{3}{|l|}{ Percent } \\
\hline & & & & \multicolumn{2}{|c|}{ Share of GDP } & \multirow{2}{*}{$\begin{array}{l}\text { Share of } \\
\text { employment }\end{array}$} \\
\hline & & & & Demand & $\begin{array}{l}\text { Value } \\
\text { added }\end{array}$ & \\
\hline Method 1 & 284.2 & 120.5 & 3,749 & 4.6 & 1.9 & 3.2 \\
\hline Method 2 & 294.9 & 124.5 & 3,933 & 4.7 & 2 & 3.3 \\
\hline Method 3 & 332.8 & 135.7 & 4,353 & 5.3 & 2.2 & 3.7 \\
\hline \multicolumn{7}{|c|}{ NOTE: See the section "Methodological Overview" for a discussion of the three methods. } \\
\hline \multicolumn{7}{|c|}{$\begin{array}{l}\text { Source: Table 1, p8, "U.S. Travel and Tourism Satellite Accounts for 1992", Sumiye Okubo and Mark A. } \\
\text { Planting, Survey of Current Business July 1998. Bureau of Economic Analysis, Reproduced with the } \\
\text { Permission obtained by the author }\end{array}$} \\
\hline
\end{tabular}

Table 2. Key Indicators of Tourism Activity: Range of Estimates, 1992

This table is the final product of TSA work, which includes how large the tourism demand is (range between $\$ 284.2$ billion and $\$ 332.8$ billion: first column from left), how large the value added of tourism activities are (range between $\$ 120.5$ billion and $\$ 135.7$ billion: second 
column from left), how many jobs are attributed to tourism activities (range between 3.7 million to 4.3 million jobs: third column from left), and relative share of those tourism activities in the whole U.S. economy by percentages shown in three columns from right under the heading of "percent". So we see the goal of TSA output at the beginning as a summary. In this example, I will not discuss the TSA with three methods, but rather on one method to explain the structure.

As you can see, these data will be very valuable for policy makers, taxpayers, government officials. If you know the relative size and significance of tourism activities as a quasi industrial sector, you can compare the tourism industry with other existing industries. Once the tourism as an industrial sector can be put in perspective, there can be rational discussions on how much of government and taxpayers resources should be allocated into this industrial sector, how much of educational resources be allocated to students and workers in these sectors, or how important is the development of this particular sector for the creation of employment for the citizens, etc.

\subsubsection{Tourism commodities}

Table 3 "Classification of Commodities in the Travel and Tourism Accounts" shows the description of tourism commodities and its contents. If you are a casual consumer of TSA, you may not find this table useful so often. If you have to develop TSA for your region/nation, suddenly this table would become useful beacon for your assignments regarding what should be included or excluded in each commodity categories. One thing I should mention would be the existence of non-tourism commodities at the bottom of the table. For example, if you look at commodities of gasoline and oil, they are not as much a tourism commodities as a rainbow T-shirt saying "Costa del Sol". But tourists in the USA probably spend more money to buy this commodity than on T-shirts. because tourists purchase these non-tourism commodities, those should be listed as non-tourism commodities that tourists purchase.

\subsubsection{TSA industries and commodities}

Table 4 shows the names of tourism industries and their corresponding commodities. Commodities are those items, tangible and intangible goods or services to be consumed by tourism activities (of visitors and non-visitors) and industries are those which produce respective commodities. If you have to produce regional/national TSA to measure the tourism activities in the study region, this table will be useful.

You may wonder if most of the industries produce only the corresponding commodities. For example, do you think whether Hotel and lodging places as an industry produce only the commodity called the Hotel and lodging places?

Tourism commodities are tourism-related goods and services that are purchased by visitors, non-visitors for final consumption and by other industries as intermediate goods.

That may be enough explanations if you had prior education as an economist. Tourism and hospitality students will also understand the meaning precisely only if at least one example is presented. 
If you are a tourist to visit overseas destination, you stay at the hotel. Imagine yourself in a foreign destination. You may be a French family staying in Prague. You may be a Dutch tourist in Aruba, Serbian tourists in Dubai, UAE, Japanese tourist in Busan, South Korea, or an American in London. What you need to consume as a tourist is the tourism-related product -a comfortable and convenient place to stay for the duration of your visit, which is produced by the hotel industry. To put this transaction in TSA perspective, we see that a tourist consumed the tourism-related product called "Hotel and Lodging Places" (in the row), which is produced by the hotel industrial sector called "Hotel and Lodging Places" (in the column).

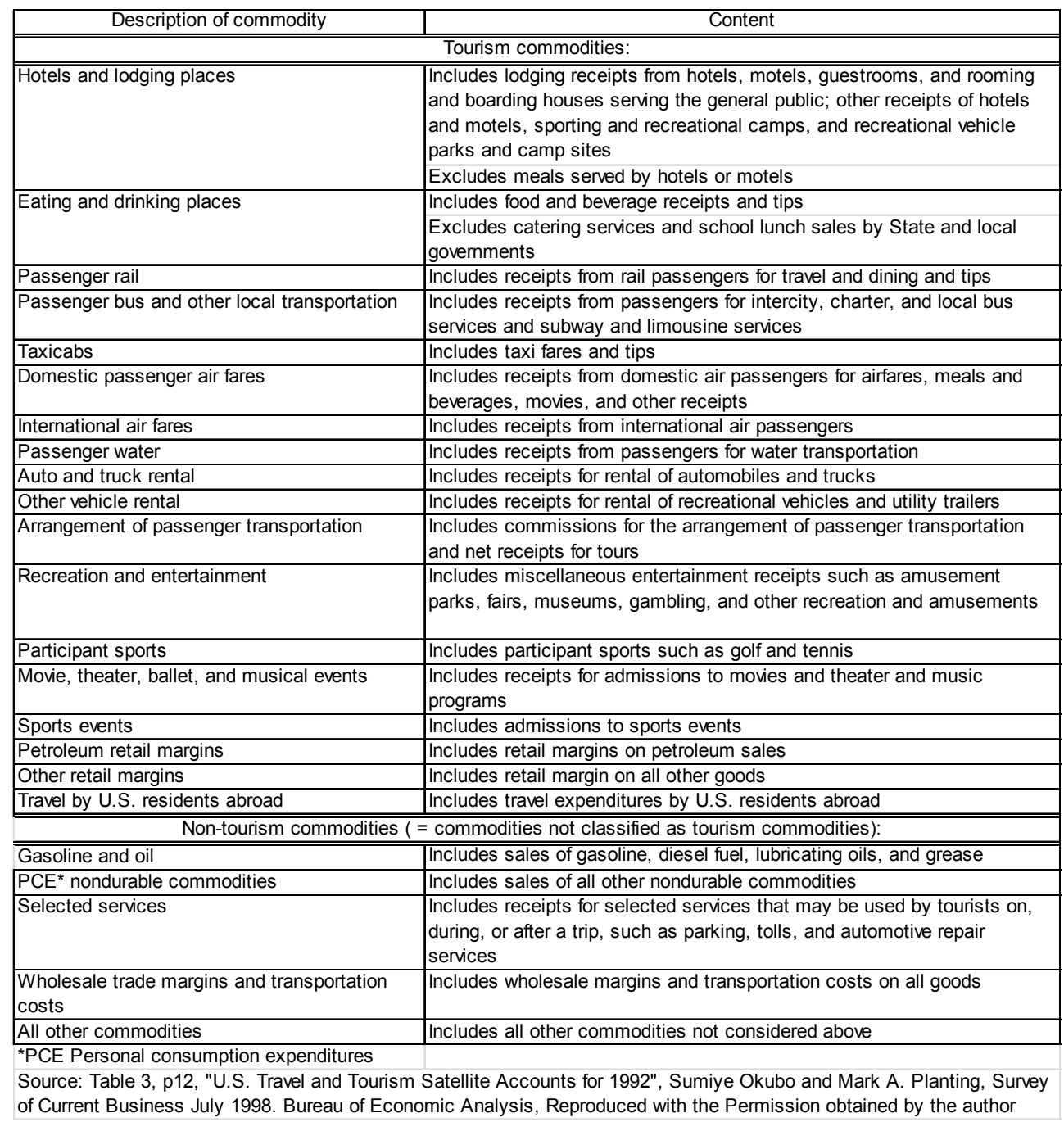

Table 3. Classification of Commodities in the Travel and Tourism Accounts 


\begin{tabular}{|c|c|}
\hline Industry & $\begin{array}{r}\text { Commodity } \\
\end{array}$ \\
\hline Hotels and lodging places & Hotels and lodging places \\
\hline Eating and drinking places & Eating and drinking places \\
\hline Railroads and related services & Passenger rail \\
\hline $\begin{array}{l}\text { Local and suburban transit and interurban highway passenger } \\
\text { transportation, except taxicabs }\end{array}$ & $\begin{array}{l}\text { Passenger bus and other local } \\
\text { transportation }\end{array}$ \\
\hline Taxicabs & Taxicabs \\
\hline Air transportation & $\begin{array}{l}\text { Domestic passenger air fares } \\
\text { International air fares }\end{array}$ \\
\hline Water transportation & Passenger water \\
\hline Automotive rental and leasing, without drivers & $\begin{array}{l}\text { Auto and truck rental } \\
\text { Other vehicle rental }\end{array}$ \\
\hline Arrangement of passenger transportation & Arrangement of passenger transportation \\
\hline $\begin{array}{l}\text { Miscellaneous amusement and recreation services (except membership } \\
\text { sports and recreation clubs); racing, including track operation; marinas; } \\
\text { libraries, museums, art galleries, and botanical and zoological gardens }\end{array}$ & Recreation and entertainment \\
\hline Membership sports and recreation clubs & Participant sports (golf, tennis, etc.) \\
\hline $\begin{array}{l}\text { Motion picture theaters; dance studios, schools, and halls; theatrical } \\
\text { producers (except motion pictures), bands, orchestras, and entertainers }\end{array}$ & Movie, theater, ballet, and musical events \\
\hline Professional sports clubs and promoters & Sports events \\
\hline Gasoline service stations & Petroleum retail margins \\
\hline Retail, excluding eating and drinking places and gasoline service stations & Other retail margins \\
\hline Industries producing nondurable PCE goods & $\begin{array}{l}\text { Personal consumption expenditures } \\
\text { (PCE) nondurable commodities }\end{array}$ \\
\hline $\begin{array}{l}\text { Automobile parking, automotive repair shops and services, and toll } \\
\text { highways }\end{array}$ & $\begin{array}{l}\text { Parking, automotive repair, and highway } \\
\text { tolls }\end{array}$ \\
\hline All other industries & $\begin{array}{l}\text { Wholesale trade margins and } \\
\text { transportation costs } \\
\text { Gasoline and oil } \\
\end{array}$ \\
\hline $\begin{array}{l}\text { (Travel by U.S. residents abroad has no industry counterpart. U.S. residents traveling } \\
\text { abroad purchase commodities that are produced abroad, and the TTSA's include only } \\
\text { domestically produced commodities) }\end{array}$ & Travel by U.S. residents abroad \\
\hline
\end{tabular}

Table 4. TTSA industries and commodities

You can find that the Hotel sector produces another commodity called "Eating and Drinking Places". Again, you have to imagine your hotel stay. Can you look for restaurant experience at the hotel? With exception of certain segment of hotels which exclusively offer only hotel rooms, many hotels have limited or full service restaurant units. Depending on the location of the hotel business, the hotel's production of restaurant commodity component could be substantial. For example, in some cities in the Middle East, it is quite common that significant hotels revenue can be attributable to sales at their Food and Beverage operations, as the role of hotels in the society is oriented more towards as a social place to meet and dine.

In this table, your knowledge on I-O will be valuable. 


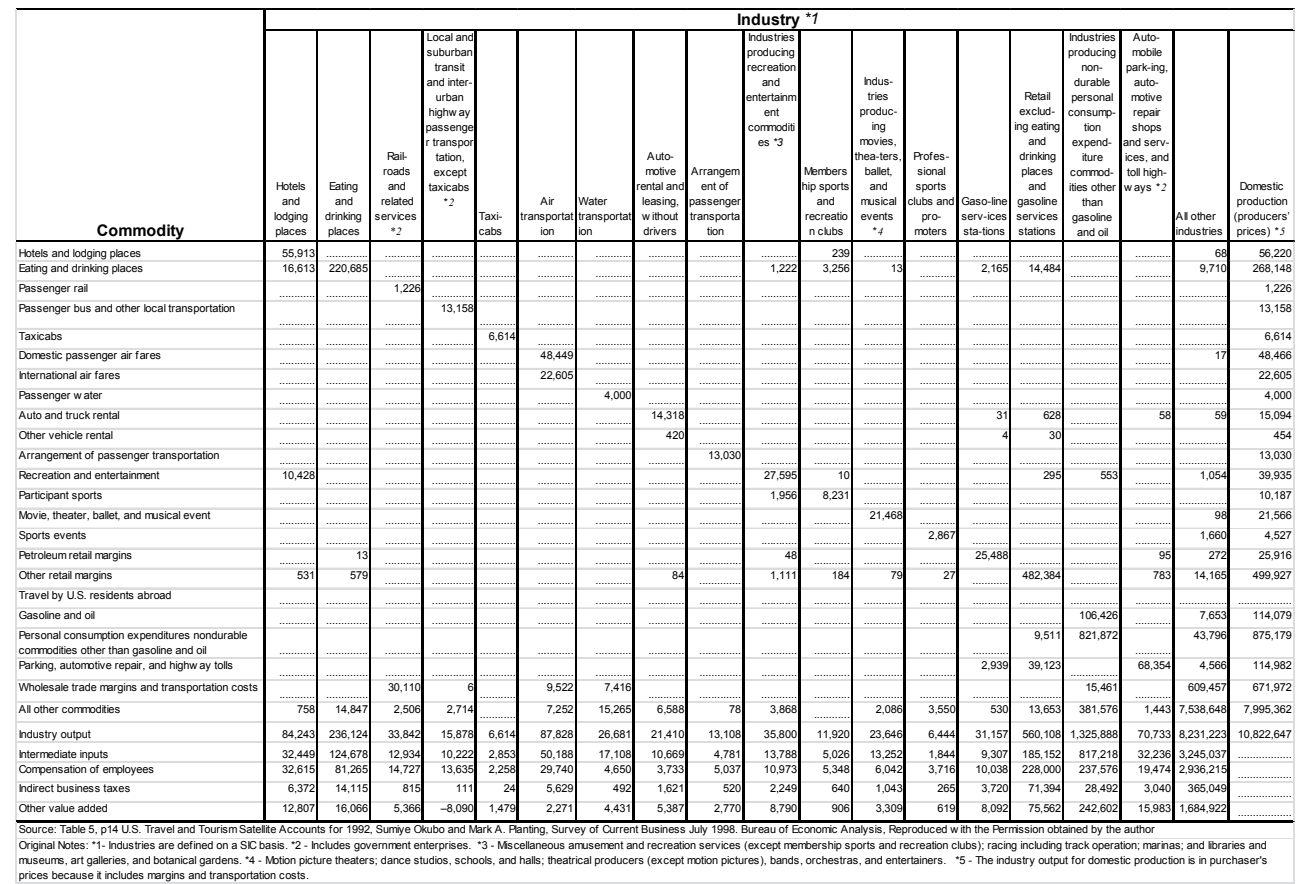

Table 5. Production Account of Tourism Industries and All Other Industries 1992 (unit: US\$ million)

\subsubsection{Column interpretations}

See the first column "Hotel and Lodging Places" industry to discuss on the cell which intersects with Industry Output. You see \$84,243 million. This means the "Hotel and Lodging Places" industry produced the total of $\$ 84,243$ million of output. If we recall that Total Output equals Total Input by definition of the I-O structure, then Total Input should equal to the sum of Intermediate Inputs and Value Added component.

Total Input $=$ Intermediate Inputs + Value Added $(=$ Compensation of Employees + Indirect Business Taxes + Other Value Added)

$84,243=32,449+(32,615+6,372+12,807)$

See upper part of the same column. Summation of all the commodities that the "Hotel and Lodging Places" industry produced should be equal to the Total Output. The industry produced five different commodities, which are "Hotel and Lodging Places", "Eating and Drinking Places", Recreation and Entertainment", "Other Retail Margins" and "All other Commodities".

Total Output $=$ "Hotel and Lodging Places" + "Eating and Drinking Places" + "Recreation and Entertainment" + "Other Retail Margins" + "All other Commodities"

$84,243=55,913+16,613+10,428+531+758$ 
Now that we have two summations of the column and the row being the same number, we can equate the Total Input with Total Output.

Total Input $=32,449+(32,615+6,372+12,807)=55,913+16,613+10,428+531+758=$ Total Output. Calculations on these summation show that Total Input equals Total Output in perfect compliance with the principles of I-O table. We can see that prior knowledge on the I-O surely help understand how the TSA tables are structured, because TSA is based on the I-O structure, which is also the basis for System of National Accounts.

\subsubsection{Row interpretations}

Let's start with "Hotel and Lodging Places' commodities" which will show you the logics of how the numbers in rows are displayed. Total productions of "Hotel and Lodging Places" commodities in the Unites States were \$56,220 million, as we see the Domestic Production at the far right number. We can see from this table which industrial sector produced "Hotel and Lodging Places' commodities" by looking at the numbers in the first row. Along the industries, "Hotel and Lodging Places" industry produced \$55,913 million of "Hotel and Lodging Places" commodities (look at the row heading on left), and "Membership sports and Recreation Clubs" produced \$239 million of "Hotel and Lodging Places" commodities. Outside of the tourism related sectors, "All other industries" also provided \$68 million of "Hotel and Lodging Places" commodities. Perhaps we should follow one more example of row interpretations.

Second row is the "Eating and drinking places" commodities which will show production of the commodities by various industrial sectors. Total productions of "Eating and drinking places" commodities in the Unites States were $\$ 268,148$ million, as we see the Domestic Production at the far right number. Compared with the comparable number for the "Hotel and Lodging Places" commodities, this number is more than four times larger. We can see from this table which industrial sector produced "Eating and drinking places" commodities by looking at the numbers in the first row.

Looking along the industries column, "Hotel and Lodging Places" industry produced $\$ 16,613$ million of "Eating and drinking places" commodities (look the row heading on left). An industrial sector called "Hotel and Lodging Places" (commonly known as "hotels") produced $\$ 16,613$ million equivalent of dining experience (perhaps combination of tasty meals, nice drink, good service and nice atmosphere, resulting in intangible commodity as dining experience). By looking at "Eating and Drinking Places" commodity (start from 2nd row heading on your left side of the table) you find many numbers along this row. Here is an important concept to remember: It is not only the restaurant industry (= Eating and Drinking Places industry) which can produce the commodity (= dining experience), but also many other industry can produce the commodity (= dining experience) such as hotels, sport stadium (have you seen people at football stadium with beers, hot dogs and popcorns?), or gas stations.

\subsubsection{Supply and consumption table (table 6)}

Having learned which industry produce respective tourism-related commodities in the previous table, you will see the next table showing how the tourism-related commodities are supplied and who actually consume the tourism-related commodities. 
In the table, you can see two large column groups of Supply and Consumption, and on the row (left), you can see exactly the same commodities items exactly the same order as in the previous table. Indeed, the first column under Domestic Production (producers' prices) is identical to the column which appeared in the far right end of the Production table.

\begin{tabular}{|c|c|c|c|c|c|c|c|c|c|c|c|c|c|}
\hline \multirow[b]{2}{*}{ Commodity } & \multicolumn{7}{|c|}{ Supply } & \multicolumn{6}{|c|}{ Consumption } \\
\hline & $\begin{array}{c}\text { Domestic } \\
\text { production } \\
\text { (producers' } \\
\text { prices) }{ }^{*} l\end{array}$ & Imports & $\begin{array}{l}\text { Govern- } \\
\text { ment sales }\end{array}$ & \begin{tabular}{|c|} 
\\
Change in \\
business \\
inven-tories
\end{tabular} & \begin{tabular}{|c|}
$\begin{array}{c}\text { Whole-sale } \\
\text { trade } \\
\text { margins and } \\
\text { transpor- } \\
\text { tation costs }\end{array}$ \\
\end{tabular} & $\begin{array}{l} \\
\text { Retail } \\
\text { margins }\end{array}$ & \begin{tabular}{|l|l} 
Total supply \\
$\star_{2}$
\end{tabular} & $\begin{array}{l}\text { Inter- } \\
\text { mediate }\end{array}$ & $\begin{array}{c}\text { Personal } \\
\text { consump- } \\
\text { tion expend } \\
\text { itures }\end{array}$ & $\begin{array}{c}\text { Gross } \\
\text { private } \\
\text { domestic } \\
\text { fixed invest } \\
\text { ment }\end{array}$ & $\begin{array}{c}\text { Exports of } \\
\text { goods and } \\
\text { services }\end{array}$ & \begin{tabular}{|c|} 
Govern- \\
ment \\
expend- \\
itures \\
excluding \\
sales *3 \\
\end{tabular} & $\begin{array}{c}\text { Total } \\
\text { consump- } \\
\text { tion }\end{array}$ \\
\hline Hotels and lodging places & 56,220 & & 357 & ............ & & & 56,577 & 27,260 & 23,680 & $\cdots \cdots \cdots \cdots$ & & 5,637 & 56,577 \\
\hline Eating and drinking places & 268,148 & ……........... & $\ldots \ldots \ldots \ldots$ & $\ldots \ldots \ldots$ & ..................... & 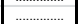 & 268,148 & 32,335 & 231,193 & $\ldots \ldots \ldots \ldots$ & 309 & 4,311 & 268,148 \\
\hline Passenger rail & 1,226 & $\ldots \ldots \ldots \ldots \ldots$ & $\ldots \ldots \ldots \ldots \ldots$ & $\ldots \ldots \ldots \ldots \ldots$ & .................... & $\ldots \ldots \ldots \ldots \ldots$ & 1,226 & 310 & 829 & $\ldots \ldots \ldots \ldots \ldots$ & $\ldots \ldots \ldots \ldots \ldots$ & 87 & 1,226 \\
\hline Passenger bus and other local transportation & 13,158 & $\ldots \ldots \ldots \ldots$ & $\ldots \ldots \ldots \ldots$ & $\ldots \ldots \ldots \ldots$ & $\ldots \ldots \ldots$ & $\ldots \ldots \ldots \ldots$ & 13,158 & 2,612 & 10,455 & $\ldots \ldots \ldots$ & $\ldots \ldots \ldots \ldots$ & 91 & 13,158 \\
\hline Taxicabs & 6,614 & & $\ldots \ldots \ldots \ldots \ldots$ & $\ldots \ldots \ldots \ldots \ldots$ & & $\ldots \ldots \ldots \ldots \ldots$ & 6,614 & 3,641 & 2,586 & $\ldots \ldots \ldots \ldots \ldots$ & & 387 & 6,614 \\
\hline Domestic passenger air fares & 48,466 & 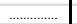 & $\ldots \ldots \ldots \ldots$ & 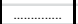 & ………......... & .................... & 48,466 & 21,971 & 21,308 & 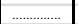 & ……..... & 5,187 & 48,466 \\
\hline International air fares & 22,605 & 9,808 & $\ldots . . . \ldots \ldots \ldots . . . . .$. & ................... & $\ldots \ldots \ldots \ldots \ldots$ & $\ldots \ldots \ldots \ldots \ldots . . . .$. & 32,413 & 3,073 & 12,377 & $\ldots \ldots \ldots \ldots \ldots$ & 16,395 & 568 & 32,413 \\
\hline Passenger water & 4,000 & 301 & $\ldots$ & $\ldots \ldots \ldots$ & $\ldots \ldots$ & $\ldots \ldots \ldots \ldots$ & 4,301 & & 4,125 & $\ldots \ldots \ldots \ldots$ & 176 & $\ldots \ldots$ & 4,301 \\
\hline Auto and truck rental & 15,094 & $\ldots \ldots \ldots \ldots . .$. & $\ldots \ldots \ldots \ldots$ & $\ldots \ldots \ldots \ldots$ & 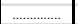 & $\ldots \ldots \ldots \ldots$ & 15,094 & 10,668 & 3,234 & $\ldots \ldots \ldots \ldots$ & $\ldots \ldots \ldots \ldots \ldots$ & 1,192 & 15,094 \\
\hline Other vehicle rental & 454 & $\ldots \ldots \ldots \ldots \ldots$ & $\ldots \ldots \ldots \ldots \ldots$ & $\ldots \ldots \ldots \ldots$ & $\ldots \ldots \ldots \ldots \ldots$ & $\ldots \ldots \ldots \ldots$ & 454 & 245 & 209 & $\ldots \ldots \ldots \ldots$ & & $\ldots \ldots \ldots \ldots \ldots$ & 454 \\
\hline Arrangement of passenger transportation & 13,030 & $\ldots \ldots \ldots \ldots \ldots$ & 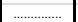 & $\ldots \ldots \ldots \ldots \ldots$ & $\ldots$ & $\ldots \ldots \ldots \ldots$ & 13,030 & 9,004 & 2,814 & 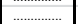 & 1,107 & 105 & 13,030 \\
\hline Recreation and entertainment & 39,935 & 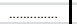 & 3,708 & $\ldots \ldots \ldots \ldots \ldots$ & 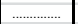 & $\ldots \ldots \ldots \ldots \ldots$ & 43,643 & 770 & 42,057 & $\ldots \ldots \ldots \ldots \ldots$ & $\ldots \ldots \ldots \ldots \ldots$ & 816 & 43,643 \\
\hline Participant sports & 10,187 & $\ldots \ldots \ldots$ & $\ldots \ldots \ldots \ldots$ & $\ldots \ldots \ldots \ldots$ & $\ldots \ldots \ldots$ & $\ldots \ldots \ldots \ldots$ & 10,187 & 1,284 & 8,903 & $\ldots \ldots \ldots \ldots$ & ……..... & $\ldots .$. & 10,187 \\
\hline Movie, theater, ballet, and musical events & 21,566 & 145 & …….............. & $\ldots \cdots \cdots$ & & ……............ & 21,711 & 8,194 & 13,313 & $\ldots \ldots \ldots$ & 43 & 161 & 21,711 \\
\hline Sports events & 4,527 & 101 & 444 & $\ldots \ldots \ldots$ & 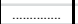 & $\ldots \ldots \ldots \ldots$ & 5,072 & 1,303 & 3,096 & $\ldots \ldots \ldots \ldots$ & 320 & 353 & 5,072 \\
\hline Petroleum retail margins & 25,916 & $\ldots \ldots \ldots \ldots . .$. & $\ldots \ldots \ldots \ldots \ldots$ & $\ldots \ldots \ldots \ldots \ldots$ & ................... & $\ldots \ldots \ldots \ldots \ldots . . . .$. & $\ldots \ldots \ldots \ldots \ldots$ & $\ldots \ldots \ldots \ldots . . . .$. & .......... & $\ldots \ldots \ldots \ldots \ldots . . .$. & $\ldots \ldots \ldots \ldots \ldots . .$. & $\ldots \ldots \ldots \ldots \ldots$ & $\ldots \ldots \ldots \ldots \ldots \ldots \ldots$ \\
\hline Other retail margins & 499,927 & & $\ldots \ldots \ldots \ldots$ & $\ldots \ldots \ldots \ldots$ & $\ldots \ldots \ldots \ldots \ldots . . .$. & $\ldots \ldots \ldots \ldots$ & & & & $\ldots \ldots \ldots \ldots \ldots$ & $\ldots \ldots \ldots \ldots$ & $\ldots \ldots \ldots \ldots \ldots$ & \\
\hline Travel by U.S. residents abroad & & 39,964 & $\ldots \ldots \ldots \ldots$ & $\ldots \ldots \ldots \ldots$ & & & 39,964 & 10,361 & 29,603 & $\ldots \ldots \ldots \ldots$ & & & 39,964 \\
\hline Gasoline and oil & 114,079 & 5,283 & ………........... & 518 & 62,204 & 25,916 & 206,964 & 78,264 & 115,234 & & 2,994 & 10,472 & 206,964 \\
\hline $\begin{array}{l}\text { Personal consumption expenditures nondurable } \\
\text { commodities other than gasoline and oil }\end{array}$ & 875,179 & 137,493 & 1,219 & 9,432 & 197,752 & 299,313 & $1,501,524$ & 415,108 & 972,568 & 2,564 & 72,583 & 38,701 & $1,501,524$ \\
\hline Parking, automotive repair, and highw ay tolls & 114,982 & ................... & 181 & 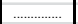 & ................. & .................... & 115,163 & 37,134 & 75,560 & $\ldots \ldots \ldots \ldots . . . .$. & 17 & 2,452 & 115,163 \\
\hline Wholesale trade margins and transportation costs & 671,972 & & & & & & & & & & & & \\
\hline All other commodities & $7,995,362$ & 438,542 & 121,167 & $-4,520$ & 412,016 & 200,614 & $9,172,221$ & $3,925,205$ & $2,635,574$ & 788,427 & 508,665 & $1,314,350$ & $9,172,221$ \\
\hline Total & $10,822,647$ & 631,637 & 127,076 & 5,430 & 671,972 & 525,843 & $11,575,930$ & \begin{tabular}{|l|}
$4,588,742$ \\
\end{tabular} & $4,208,718$ & 790,991 & 602,609 & $1,384,870$ & $11,575,930$ \\
\hline
\end{tabular}

Table 6. Supply and Consumption of Tourism and All Other Commodities, 1992 (Unit in US\$ million)

\subsubsection{Interpretation of total supply and total consumption of commodities}

At around the middle of the columns, you find a column in the name of "Total supply", which show the row-wise sums of each commodity. If you look at the first row of "Hotels and lodging places" commodity, \$56,220 million equivalent of "Hotels and lodging places" commodity were supplied by the "Domestic production" (top, far left) of which details can be traced back in the previous table. "Hotels and lodging places" commodities are supplied by "Government sales" for $\$ 357$ million, making the total supply of "Hotels and lodging places" commodities to be $\$ 56,577$ million.

Total consumption will be met by total supply, and the way this table is made will intrigue you, if you have learned about concepts of Input-Output. The first column under Consumption is "Intermediate", which is the demand for "Hotels and lodging places" commodity from other industrial sectors as intermediate goods and services.

\section{[Examples of Intermediate goods and Final Consumption]}

Examples of such transaction includes Hotel's sales of hotel rooms to Online Travel Companies (OTCs) which buy those "intermediate goods" from hotels and immediately sell those as "final goods" to consumers (you and me). From hotels' point of view, though they have identical rooms, some are sold as final products to consumers (you and me, visiting Marriott.com, or Hyatt.com to buy rooms at Marriott or Hyatt hotels, for example) and some 
other rooms are sold as intermediate goods to OTCs, which in turn sell the same room to consumers (you and me, visiting orbitz.com or Travelocity.com to buy rooms at Marriott or Hyatt hotels).

"Hotels and lodging places" commodity to be used as intermediate goods and services for other industrial sectors production activities was $\$ 27,260$ million, which was larger than the "Personal consumption expenditures" for $\$ 23,680$ million. Consumption by governments and their employees was captured under the column "Government expenditures excluding sales" for $\$ 5,637$ which is about $10 \%$ of total consumption of "Hotels and lodging places" commodity. If you look across the different commodities, there are four other commodities of which consumption from other industrial sectors were larger than personal consumption expenditures.

When you look at the columns under the Consumption, what you see here are from left to right, Intermediate, Personal Consumption, Investment, Exports, and Government Expenditure. So it is AX, C, I, EX, G. You have Imports (IM) under the supply. With all those information, you can calculate the GDP of the Unites States in 1992 using the numbers at the bottom Total rows, if you remember that GDP $=\mathrm{C}+\mathrm{I}+\mathrm{G}+\mathrm{EX}-\mathrm{IM}$.

\subsubsection{Tourism demand by type of visitor (table 7)}

This table appears to be a tough one for students to follow. Inclusion of three Methods in the same table adds its complexity on the appearance of the table. Basic structure of this table can be simply shown as follows.

\begin{tabular}{|c|c|c|c|c|c|c|c|c|c|c|c|c|c|c|c|c|c|c|c|c|}
\hline \multirow[b]{3}{*}{ Commodity } & \multirow{3}{*}{$\begin{array}{l}\text { Total } \\
\text { demand }\end{array}$} & \multicolumn{13}{|c|}{ Tourism demand } & \multicolumn{3}{|c|}{ Nontourism demand } & \multicolumn{3}{|c|}{ ratio 1} \\
\hline & & \multicolumn{3}{|c|}{ Total tourism demand } & \multicolumn{3}{|c|}{ Business } & \multicolumn{3}{|c|}{\begin{tabular}{|l|}
$\begin{array}{l}\text { Government } \\
\text { expenditures excl. sales }\end{array}$ \\
\end{tabular}} & \multicolumn{3}{|c|}{ Resident households } & \multirow[b]{2}{*}{ residents } & \multirow[b]{2}{*}{ Method 1} & \multirow[b]{2}{*}{ Merod 2} & \multirow[b]{2}{*}{ Method 3} & \multirow[b]{2}{*}{1.} & \multirow[b]{2}{*}{2} & \multirow[b]{2}{*}{3} \\
\hline & & Method 1 & Method 2 & Method 3 & Menod 1 & Method 2 & Method 3 & Method 1 & Metrod 2 & Method 3 & & & & & & & & & & \\
\hline Hotels and lodging places & 56,577 & \begin{tabular}{|c|c|c|}
56,577 \\
\end{tabular} & 56,577 & 56,577 & 27,260 & 27,260 & 27,260 & 5,637 & 5,637 & 5,637 & 11,342 & 11,342 & 11,342 & 12,338 & & & & & & \\
\hline Eating and drinking places & 268,148 & 45,431 & 48,685 & 58,484 & 17,917 & 17,917 & 17,917 & 3,696 & 3,696 & 3,696 & 13,812 & 17,066 & 26,865 & 10,006 & 222,717 & 219,463 & 209,664 & 0.17 & 0.18 & 0.22 \\
\hline Passenger rail & 1,226 & 1,226 & 1,226 & 1,226 & 310 & 310 & 310 & 87 & 87 & 87 & 653 & 653 & 653 & 176 & & & & & & \\
\hline Passenger bus and other local transportation & 13,158 & 3,367 & 3,934 & 4,898 & 583 & 698 & 893 & 55 & 57 & 61 & 2,170 & 2,620 & 3,385 & 559 & 9,791 & 9,224 & 8,260 & 0.26 & 0.3 & 0.37 \\
\hline Taxicabs & 6,614 & 1,478 & 3,002 & 4,624 & 748 & 1,592 & 2,490 & 71 & 152 & 237 & 531 & 1,130 & 1,769 & 128 & 5,136 & 3,612 & 1,990 & 0.22 & 0.45 & 0.7 \\
\hline Domestic passenger air fares & 48,466 & 48,466 & 48,466 & 48,466 & 21,971 & 21,971 & 21,971 & 5,187 & 5,187 & 5,187 & 16,773 & 16,773 & 16,773 & 4,535 & & & $\ldots \ldots$. & 1 & 1 & \\
\hline International air fares & 32,413 & 32,159 & 32,159 & 32,159 & 3,073 & 3,073 & 3,073 & 314 & 314 & 314 & 12,377 & 12,377 & 12,377 & 16,395 & 254 & 254 & 254 & 0.99 & 0.99 & 0.99 \\
\hline Passenger water & 4,301 & 4,150 & 4,150 & 4,150 & & & & & & & 3,138 & 3,138 & 3,138 & 1,012 & 151 & 151 & 151 & 0.96 & 0.96 & 0.96 \\
\hline Auto and truck rental & 15,094 & 12,132 & 12,132 & 12,689 & 8,400 & 8,400 & 8,400 & 1,055 & 1,055 & 1,055 & 2,207 & 2,207 & 2,764 & 470 & 2,962 & 2,962 & 2,405 & 0.8 & 0.8 & 0.84 \\
\hline Other vehicle rental & 454 & 125 & 209 & 209 & & $\ldots \ldots \ldots$. & . & & & & 101 & 185 & 185 & 24 & 329 & 245 & 245 & 0.28 & 0.46 & 0.46 \\
\hline Arrangement of passenger transportation & 13,030 & 2,919 & 2,919 & 2,919 & $\ldots \ldots$. & ............. & $\ldots . . . . .$. & 105 & 105 & 105 & 1,975 & 1,975 & 1,975 & 839 & 10,111 & 10,111 & 10,111 & 0.22 & 0.22 & 0.22 \\
\hline Recreation and entertainment & 43,643 & 14,509 & 15,500 & 17,547 & & & & $1 \ldots$ & & & 9,820 & 10,811 & 12,858 & 4,689 & 29,134 & 28,143 & 26,096 & 0.33 & 0.36 & 0.4 \\
\hline Participant sports & 10,187 & 3,575 & 3,678 & 4,781 & 1,207 & 1,207 & 1,207 & $\ldots \ldots \ldots$ & $\ldots \ldots \ldots$ & $\ldots \ldots . .$. & 1,747 & 1,850 & 2,953 & 621 & 6,612 & 6,509 & 5,406 & 0.35 & 0.36 & 0.47 \\
\hline Movie, theater, ballet, and musical events & 21,711 & 3,973 & 4,673 & 6,475 & 820 & 820 & 820 & $\ldots \ldots . .$. & $\ldots \ldots . . .$. & .......... & 2,326 & 3,026 & 4,828 & 827 & 17,738 & 17,038 & 15,236 & 0.18 & 0.22 & 0.3 \\
\hline Sports events & 5,072 & 1,464 & 1,385 & 1,800 & 413 & 413 & 413 & ......... & $\ldots \ldots \ldots$ & $\ldots \ldots . .$. & 775 & 696 & 1,111 & 276 & 3,608 & 3,687 & 3,272 & 0.29 & 0.27 & 0.35 \\
\hline Travel by U.S. residents abroad & 39,964 & 39,964 & 39,964 & 39,964 & 10,361 & 10,361 & 10,361 & & & & 29,603 & 29,603 & 29,603 & & & & & 1 & & \\
\hline Gasoline and oil & 206,964 & 11,208 & 11,864 & 17,485 & 2,067 & 2,210 & 3,434 & 181 & 194 & 300 & 7,251 & 7,751 & 12,042 & 1,709 & 195,756 & 195,100 & 189,479 & 0.05 & 0.06 & 0.08 \\
\hline $\begin{array}{l}\text { Personal consumption expenditure nondurable } \\
\text { commodities other than gasoline and oil }\end{array}$ & $1,501,524$ & 35,384 & 37,362 & 47,443 & & & & & & & 18,599 & 20,577 & 30,658 & 16,785 & $1,466,140$ & $1,464,162$ & $1,454,081$ & 0.02 & 0.02 & 0.03 \\
\hline Parking, automotive repair, and highw ay tolls & 115,163 & 6,077 & 7,008 & 10,852 & 109 & 197 & 303 & 61 & 101 & 158 & 5,769 & 6,572 & 10,253 & 138 & 109,086 & 108,155 & 104,311 & 0.05 & 0.06 & 0.09 \\
\hline All other commodities & $9,172,221$ & & & & & & & & & & & & & & $9,172,221$ & $9,172,221$ & $9,172,221$ & & & \\
\hline Total & $11,575,930$ & 324,184 & 334,893 & 372,748 & 95,239 & 96,429 & 98,852 & 16,449 & 16,585 & 16,837 & $\mid 140,969$ & 150,352 & 185,532 & 71,527 & $11,251,746$ & $11,241,037$ & $11,203,182$ & & $\ldots$ & \\
\hline
\end{tabular}

Table 7. Tourism Demand by Type of Visitor, 1992

\subsubsection{Tourism demand and non-tourism demand}

At the top left column of the table 7 , you have "Total demand" column. You see familiar names of commodities, identical from the top commodity "Hotels and lodging places" to the bottom "All other commodities" except margins items in the Supply and Consumption of Tourism and All Other Commodities table. Total demand can be disaggregated into Nontourism demand and Tourism demand, which will be further disaggregated into Business, Government expenditure excluding sales, resident household and Nonresidents. 
Let's look at examples. First row is the "Hotel and lodging places" commodities for which there was $\$ 56,577$ million of "Total demand". Hotel and lodging places" commodities are unique commodities in that demand for them consist of $100 \%$ Tourism demand, and none from Nontourism demand. Again, we have to be reminded that tourism demand derive from visitors who can be either leisure-visitors (= tourists) or non-leisure visitors and that tourism demand includes, as you clearly see, demand from Business, Governments and Nonresidents who may come as leisure traveler or foreign Business or Governments workers. Total tourism demand for $\$ 56,577$ million were generated from Business for $\$ 27,260$ million (48.2\%), Government Expenditure for \$5,637 million (10.0\%), Resident Household for $\$ 11,342$ million (20.0\%), and Nonresidents for $\$ 12,338$ million (21.8\%). Since Total demand for Hotel and lodging places" commodities equal total tourism demand for Hotel and lodging places" commodities, the tourism commodity ration is 1.00 .

Tourism Commodity Ratio $=$ Total Tourism Demand $/$ Total Demand .

Second row in Commodity is "Eating and drinking places" commodity. While the total demand for "Eating and drinking places" commodity is $\$ 268,148$ million, Total tourism demand is $\$ 45,431$ million based on Method 1 data. With these two numbers, we can calculate the tourism commodity ratio as $\$ 45,431 / \$ 268,148=0.17=17 \%$.

While "Eating and drinking places" commodity is consumed by Nontourism demand for $\$ 222,717$ million, we will decompose the total tourism demand into four subgroups. Business consumes for $\$ 17,917$ million equivalent of "Eating and drinking places" commodity, Government for $\$ 3,696$ million, Resident household for $\$ 13,812$ million and Nonresidents for $\$ 10,006$ million.

\subsubsection{Tourism GDP calculations (Table 8: originally Table 8)}

The table 8 , which is shown as table 8 in the original publication, displays importance of tourism industries and other industries for the production of tourism output and tourismrelated value added. Each industry produces output and certain portion of the output are purchased by visitors. That portion purchased by visitors is shown as "tourism-industry ratio" in this table. This is a very important table for policy makers and government officials because this table will enable them to explain to taxpayers and stakeholders the significance of tourism as an industry to the national/regional economy with hard numbers.

First we will look at where all numbers in this table came from.

\subsubsection{Industry output column}

Numbers in Industry output column came from the "Industry Output" row, the 5th row from the bottom in the original Table 5. The numbers shown in row vector in Table 5 are transposed into column vector.

\subsubsection{Intermediate consumption column}

Numbers in Intermediate consumption column came from the "Intermediate inputs" row. So the numbers shown in row vector in Table 5 are transposed into column vector. 
Intermediate inputs are shown next to Industry output data in table 5 and Intermediate consumption are shown next to Industry output data in table 8.

\begin{tabular}{|c|c|c|c|c|c|c|c|}
\hline \multirow[b]{2}{*}{ Industry } & \multirow{2}{*}{$\begin{array}{l}\text { Industry } \\
\text { output }\end{array}$} & \multirow{2}{*}{$\begin{array}{l}\text { Intermediate } \\
\text { consumption }\end{array}$} & \multirow{2}{*}{$\begin{array}{l}\text { Value } \\
\text { added }\end{array}$} & $\begin{array}{l}\text { Tourism } \\
\text { industry } \\
\text { ratio * } 1 \\
\end{array}$ & $\begin{array}{c}\text { Tourism } \\
\text { output }\end{array}$ & $\begin{array}{c}\text { Tourism } \\
\text { industry } \\
\text { intermediate } \\
\text { consumption } \\
\end{array}$ & $\begin{array}{c}\text { Tourism } \\
\text { industry } \\
\text { value } \\
\text { added } \\
\end{array}$ \\
\hline & & & & Method 1 & Method 1 & Method 1 & Method 1 \\
\hline Hotels and lodging places & 84,243 & 32,449 & 51,794 & 0.8 & 67,603 & 26,039 & 41,563 \\
\hline Eating and drinking places & 236,124 & 124,678 & 111,446 & 0.16 & 37,403 & 19,749 & 17,653 \\
\hline Railroads and related services & 33,842 & 12,934 & 20,908 & 0.04 & 1,226 & 469 & 757 \\
\hline $\begin{array}{l}\text { Local and suburban transit and interurban } \\
\text { highw ay passenger transportation, except } \\
\text { taxicabs }\end{array}$ & 15,878 & 10,222 & 5,656 & 0.21 & 3,367 & 2,168 & 1,199 \\
\hline Taxicabs & 6,614 & 2,853 & 3,761 & 0.22 & 1,478 & 638 & 840 \\
\hline Air transportation & 87,828 & 50,188 & 37,640 & 0.81 & 70,877 & 40,426 & 30,451 \\
\hline Water transportation & 26,681 & 17,108 & 9,573 & 0.14 & 3,860 & 2,475 & 1,385 \\
\hline Automotive rental and leasing, w ithout drivers & 21,410 & 10,669 & 10,741 & 0.54 & 11,626 & 5,793 & 5,832 \\
\hline Arrangement of passenger transportation & 13,108 & 4,781 & 8,327 & 0.22 & 2,919 & 1,065 & 1,854 \\
\hline $\begin{array}{l}\text { Miscellaneous amusement and recreation } \\
\text { services (except membership sports and } \\
\text { recreation clubs); racing including track } \\
\text { operation; marinas; and libraries and museums, } \\
\text { art galleries, and botanical and zoological } \\
\text { gardens }\end{array}$ & 35,800 & 13,788 & 22,012 & 0.18 & 6,465 & 2,490 & 3,975 \\
\hline Membership sports and recreation clubs & 11,920 & 5,026 & 6,894 & 0.31 & 3,686 & 1,554 & 2,132 \\
\hline $\begin{array}{l}\text { Motion picture theaters; dance studios, schools, } \\
\text { and halls; theatrical producers (except motion } \\
\text { pictures), bands, orchestras, and entertainers }\end{array}$ & 23,646 & 13,252 & 10,394 & 0.17 & 3,932 & 2,204 & 1,729 \\
\hline Professional sports clubs and promoters & 6,444 & 1,844 & 4,600 & 0.13 & 828 & 237 & 591 \\
\hline Gasoline service stations & 31,157 & 9,307 & 21,850 & 0.07 & 2,199 & 657 & 1,542 \\
\hline $\begin{array}{l}\text { Retail excluding eating and drinking places and } \\
\text { gasoline services stations }\end{array}$ & 560,108 & 185,152 & 374,956 & 0.02 & 13,376 & 4,422 & 8,954 \\
\hline Total tourism industries & $1,270,477$ & 529,045 & 741,432 & ............... & 230,844 & 110,384 & 120,460 \\
\hline Total all other industries & $9,552,170$ & $4,059,697$ & $5,492,473$ & & & & \\
\hline Total & $10,822,647$ & $4,588,742$ & $6,233,905$ & & & & \\
\hline
\end{tabular}

Source: Table 8, p17, "U.S. Travel and Tourism Satellite Accounts for 1992", Sumiye Okubo and Mark A. Planting, Survey of Current Business July 1998. Bureau of Economic Analysis, Reproduced with the Permission obtained by the author

Original Notes: * 1 - The industry tourism ratio is equal to tourism output divided by industry output. * 2 - The industry tourist output is derived from table 5 and table 7. The tourism commodity ratio (table 7) is multiplied by the tourism commodities produced by industries (table 5) and summed by industry. For example, the air industry produces $\$ 48,449$ million domestic passenger air fares of which 100 percent is tourism, it also produces $\$ 22,605$ million international air fares of which 99 percent is tourism. The total tourism output of the industry is $\$ 70,877$ million. Note - See the section "Methodological Overview " for a discussion of the three methods.

Table 8. Shortened Version of Original Table 8 - Tourism GDP of Tourism Industries and Other Industries, 1992

\subsubsection{Value added column}

Numbers in Value added column in Table 8 does not appear to have a corresponding row in the bottom part in the original Table 5. For example, the first number in the column " 51,794 " is the value-added for Hotels and lodging places in Table 8, but we cannot find the same number in the original Table 5. So how can we obtain this number?

If we remember how the table 5 was created, together with the basic knowledge of the I-O structure, we can find the data. Let's review how the first column (Hotels and lodging places column, the first from left) 
Total Input $=$ Intermediate Inputs + Value Added $(=$ Compensation of Employees + Indirect Business Taxes + Other Value Added)

$84,243=32,449+(32,615+6,372+12,807)$

If we sum up the value added portion $32,615+6,372+12,807$, then we will get 51,794 , which is the number we see in the top of value added column. Sum up the three numbers from bottom shown in each column.

Now, we are entering into the parts which can be challenging not only for hospitality and tourism students but also for other students with quantitative majors such as engineering or applied economics. In order to discuss tourism industry ratio, we have to understand how we calculate the tourism industry output.

\subsubsection{Tourism industry output}

We will estimate tourism industry output by taking the respective tourism commodities produced by industries (displayed in Table 5) to be multiplied by corresponding tourism commodity ratio (in Table 7). After that, results have to be summed up by industry. Let's take some examples to show the processes of calculations.

Taxicabs (with one commodity)

- There is only one commodity that Taxicabs industry produce - taxicabs as a commodity, or "a service of an efficient transportation by motor vehicle to move you and your belongings from one point to other point(s) with a dedicated driver chartered for you" to aid your imagination.

- The amount of this commodity produced and consumed was $\$ 6,614$ million as you can see at the intersection between "Taxicabs" industry column and "Taxicab" commodity row in Table 5.

- Then take that number $(\$ 6,614$ million) and look at "Tourism commodity ratio" columns at the very right bottom end of Table 7 .

- Identify the corresponding "Tourism commodity ratio" for the Taxicab commodity, in this case 0.22 .

- Total amount of commodity produced shall be multiplied by its tourism commodity ration, in this case 0.22 .

- $\$ 6,614$ million $\times 0.2234653=\$ 1,478$ million. Because there is only one commodity that Taxicabs industry produces, this is the taxicab industry's tourism output.

Air transportation (with two commodities)

- There are two commodities that Air transportation industry produces - Domestic passenger air fares and International air fares as commodities, or "a service of an efficient transportation by airplane to move you and your belongings from one point to other point(s: this can be domestic destination or in other nation) with a dedicated seat reserved for you" to aid your imagination.

- The amount of first commodity produced and consumed was $\$ 48,449$ million as you can see at the intersection between "Air transportation" industry column and "Domestic passenger air fares" commodity row in Table 5. 
- The amount of the second commodity produced and consumed was $\$ 22,605$ million as you can see at the intersection between "Air transportation" industry column and "International air fares" commodity row in Table 5.

- Then take those two numbers (\$48,449 million and \$22,605 million) and look at "Tourism commodity ratio" columns at the very right bottom end of Table 7.

- Identify the corresponding "Tourism commodity ratio" for the Domestic passenger air fares commodity, in this case 1.00, and one for the International air fares commodity, in this case 0.99 (to say exactly, it must be 0.992167 ..).

- Total amount of commodity produced shall be multiplied by its tourism commodity ration, in this case 1.00 and .99 (to say exactly, it must be $0.992167 .$.$) .$

Since the exact tourism commodity ratios are not displayed but rounded ones are shown in the Table, we may encounter rounding errors with multiple commodities under one industry. In this case, the exact ratio can be traced back because one of the two tourism commodity ratios are 1.00 .

- Because there are two commodities that Air transportation industry produces, summation of those numbers will be the Air transportation industry's tourism output. Thus, $(\$ 48,449$ million $\times 1.00)+(\$ 22,605$ million $\times 0.992167)=\$ 70,877$ million.

Eating and drinking places (with three commodities)

- $\quad$ There are three commodities that Eating and drinking places industry produce - Eating and drinking places, Petroleum retail margins, and Other retail margins as commodities, or "a service of providing you with a tasty meals, wines, beers and perhaps hot dogs, sodas, maps, sun-glasses, small gifts and fill your gasoline tank" to aid your imagination.

- The amount of first commodity produced and consumed was $\$ 220,685$ million as you can see at the intersection between "Eating and drinking places" industry column and "Eating and drinking places" commodity row in Table 5.

- The amount of the second commodity produced and consumed was \$13 million as you can see at the intersection between "Eating and drinking places" industry column and "Petroleum retail margins" commodity row in Table 5.

- The amount of the third commodity produced and consumed was $\$ 579$ million as you can see at the intersection between "Eating and drinking places" industry column and "Other retail margins" commodity row in Table 5.

- Then take those four numbers (\$220,685 million, \$13 million and \$579 million) and look at "Tourism commodity ratio" columns at the very right bottom end of Table 7.

- Identify the corresponding "Tourism commodity ratio" (we use only Method 1 for display purposes).

Eating and Drinking places $\quad=\quad 0.17$

Gasoline and oil $\quad=\quad 0.05$

Other retail margins $\quad=\quad 0.02$

- Each three of the total amount of commodity produced shall be multiplied by their respective tourism commodity ratio, in this case $0.17,0.05$ and 0.02 . ( 0.17 can be 0.1694305 to match the number - rounding errors may exist)

- Because there are three commodities that Eating and drinking places industry produce, summation of those numbers will be the Eating and drinking places industry's tourism 
output. Thus, $(\$ 220,685$ million $\times 0.17)+(\$ 13$ million $\times 0.05)+(\$ 579$ million $\times 0.02)=$ $\$ 37,403$ million.

- Identify the corresponding "Tourism commodity ratio" (we use only Method 1 for display purposes).

Hotels and lodging places

$=\quad 1.00$

Eating and Drinking places

$=\quad 0.17$

Recreation and entertainment $\quad=\quad 0.33$

Other retail margins $\quad=\quad 0.02$

- Each four of the total amount of commodity produced shall be multiplied by their respective tourism commodity ratio, in this case 1.00, 0.17, 0.33 and 0.99 .

- Because there are four commodities that Hotels and lodging places industry produce, summation of those numbers will be the Hotel and lodging places industry's tourism output. Thus, $(\$ 55,913$ million $\times 1.00)+(\$ 16,613$ million $\times 0.17)+(\$ 10,428$ million $\times 0.33)$ $+(\$ 531$ million $\times 0.02)=\$ 67,603$ million.

\subsubsection{Tourism industry ratio}

As discussed, tourism-affiliated industrial sectors can produce tourism commodities, such as hotel's production of "a comfortable place to stay". We also learned in Table 7 that those tourism-affiliated industrial sectors production of tourism commodities are not always $100 \%$ $(=1.00)$ even though four commodities, namely "Hotel and lodging places", "Passenger rail", "Domestic passenger air fares", "Travel by U.S. resident abroad" are considered to be $100 \%$ (= 1.00) consumed by tourism demand. That is the "Tourism Commodity Ratio" which shows the size of tourism demand in the total demand.

Tourism industry ratio is to show the share of visitors' purchases of tourism-affiliated industrial sectors' output, which may include purchases by non-visitors. In other words, tourism output, to be purchased by visitors, is hidden within the total output. Therefore we need a satellite to analyse the component of the total output. What we try to do here is to extract the portion of output purchased by visitors, and that can be defined as tourism output. This has been the discussion on the left half of the Table 8 .

\subsubsection{Tourism industry intermediate consumption}

The right side of the Table 8 starts from the discussion on Tourism output and subsequent decomposition of the tourism output into two components. Tourism output of the industry can be further divided into two components of Tourism industry intermediate consumption and tourism industry value added as we do so with the I-O table. To calculate the Tourism Industry Intermediate Consumption, take the Intermediate consumption (second column from left) to be multiplied by the corresponding Tourism industry ratio and the result will be Tourism industry intermediate consumption.

For example, for the Hotel and lodging places,

$\$ 32,449 \mathrm{M} \quad \mathrm{x} \quad 0.80$ (to say exactly, it must be 0.80247 ) $\quad=\$ 26,039 \mathrm{M}$

Intermediate consumption $\mathrm{x}$ tourism industry ratio

$=$ Tourism industry intermediate consumption 
For the Eating and drinking places,

$\$ 124,678 \mathrm{M} \quad \mathrm{x} \quad 0.16$ (to say exactly, it must be 0.15840 ) $\quad=\$ 19,749 \mathrm{M}$

Intermediate consumption $x$ tourism industry ratio

$=$ Tourism industry intermediate consumption

By continuing this calculation, you will have Tourism industry intermediate consumption column completed.

\subsubsection{Tourism industry value added}

Another part of decomposed component is the Tourism industry value added. To calculate the Tourism Industry Intermediate Consumption, take the Value added (third column from left) to be multiplied by the corresponding Tourism industry ratio and the result will be Tourism industry value added.

For example, for the Hotel and lodging places,

$\$ 51,794 \mathrm{M} \quad \mathrm{x} \quad 0.80$ (to say exactly, it must be 0.80247 ) $\quad=\$ 41,563 \mathrm{M}$

Value added $\mathrm{x} \quad$ tourism industry ratio $\quad=$ Tourism industry value added

For the Eating and drinking places,

$\$ 111,446 \mathrm{M} \quad \mathrm{x} \quad 0.16$ (to say exactly, it must be 0.15840 ) $\quad=\$ 17,653 \mathrm{M}$

Value added $\mathrm{x}$ tourism industry ratio $\quad=$ Tourism industry value added

By continuing this calculation, you will have Tourism industry value added column completed.

\subsubsection{Tourism industry's output and GDP}

Based on technical parts of the table 8, you may wonder what to do with the complete table. If we look at the bottom rows of the table, you see "Total tourism industries", "Total all other industries" and "Total" rows. By looking at those rows, we will see how we can use this table.

\subsubsection{Total tourism industries row}

Tourism affiliated industry's total output is $\$ 1,270,477$ million, which is a very large number. Out of the total output, $\$ 529,045$ million $(41 \%)$ is used as intermediate consumption, which means they are used by other industrial sectors to produce their final products. $\$ 741,432$ million (59\%) is used to satisfy the final consumption. However, as you see "Retail excluding eating and drinking places and gasoline service stations" industry, there are lots of industry outputs which are used for non-tourism related consumptions. For example, even though "Retail excluding eating and drinking places and gasoline service stations" industry produced total output of $\$ 560,108$ million, only a very small fraction of $\$ 13,376$ million $(0.02=$ to be exactly, it must he $0.02388=2.388 \%)$ can be attributed to tourism output, or output to be consumed by either tourism industry intermediate consumption or tourism industry value added. 
Tourism output ( $\$ 230,844$ million) can be decomposed into tourism industry intermediate consumption for $\$ 110,384$ million and Tourism industry value added for $\$ 120,460$ million.

\subsubsection{Total all other industries row and total row}

Those last two rows appear to be just bunch of large numbers, but it is very important to have those numbers so that we can put tourism as an industry in broader perspective in the society.

Total for $\$ 10,822,647$ million ( $\$ 10.8$ trillion) is the total output of the U.S. economy in the study year of 1992. With the knowledge of total size of economy, tourism Output for $\$ 230,844$ million (method 1) can be put in perspective.

- $\quad$ Relative Size of Tourism Output to the Total U.S. Output

- $\$ 230,844 \mathrm{M}(\operatorname{method} 1) / \$ 10,822,647 \mathrm{M}=2.13 \%$

- $\$ 238,578 \mathrm{M}$ (method 1) / $\$ 10,822,647 \mathrm{M}=2.20 \%$

- $\$ 259,517 \mathrm{M}($ method 1$) / \$ 10,822,647 \mathrm{M}=2.39 \%$

Next, let's look at the size of Value Added, which is basically the GDP, namely total market value of goods and services produced in the nation in one year. Total U.S. GDP was $\$ 6,233$, 905 million in the study year of 1992. With the knowledge of total size of economy, tourism value added for $\$ 120,460$ million (method 1 ) can be put in perspective.

- $\quad$ Relative Size of Tourism GDP Contribution to the Total U.S. GDP

- $\$ 120,460 \mathrm{M}(\operatorname{method} 1) / \$ 6,233,905 \mathrm{M}=1.93 \%$

- $\$ 124,528 \mathrm{M}(\operatorname{method} 1) / \$ 6,233,905 \mathrm{M}=2.00 \%$

- $\$ 135,720 \mathrm{M}(\operatorname{method} 1) / \$ 6,233,905 \mathrm{M}=2.17 \%$

With the size and significance of economic power of tourism as an industry, you can ask for legislative support for the industry, budget allocations, local community support more effectively than just a mere emotional appeals of tourism without numbers. But there is one more important set of data that you want to prepare to make your argument even more convincing. That is to be explained in the next table.

\subsubsection{Tourism employment and compensation of employees}

We have to understand why these employment-related data are highly important and influential to many stakeholders in the society. In a democratic society, or most of the nation where the national/regional leaders take responsibility for their leadership, any industrial policy has to be explained to the taxpayers to seek for their support, approval of budget, allocation of funding or positive benefits of certain policies to put those policies in perspective. This is because those governments are dependent on tax revenues which are generated from taxpayers/voters/residents. People want to know how their tax revenues are allocated and what the returns on those allocations of funds are. One of the major weaknesses of tourism as an industry has been the lack of hard numbers as a comparable industry in the national/regional economy. Thanks to TSA, we are trying to overcome the weaknesses and present tourism as an industry.

The last table in TSA presentations is a very important table for the purpose of proving validity of tourism as an industry by showing how many jobs are attributable to tourism as an industry and how much are the average annual salaries workers receive in different industrial sectors which produce tourism commodities. 


\section{Tourism Employment and Compensation (table 9)}

For the explanations purposes, table 5 is the shortened version. The table only shows data based on method 1 only on behalf of clarity.

Employment and compensation data are not the formal part of the I-O/SAM tables, while creation of table are manageable as long as you have both access to good labor-related data of your study region and basic knowledge of structural components of the I-O/SAM tables.

\begin{tabular}{|c|c|c|c|c|c|c|}
\hline \multirow{2}{*}{\begin{tabular}{|c|c|} 
\\
Industry
\end{tabular}} & \multirow[b]{2}{*}{$\begin{array}{c}\text { Total } \\
\text { employment } \\
\text { (thousands } \\
\text { of } \\
\text { employees) }\end{array}$} & \multirow{2}{*}{\begin{tabular}{|c|}
$\begin{array}{c}\text { Tourism } \\
\text { industry } \\
\text { ratio }\end{array}$ \\
\\
Method 1 \\
\end{tabular}} & \multirow{2}{*}{\begin{tabular}{|c|}
$\begin{array}{c}\text { Tourism } \\
\text { employment } \\
\text { (thousands of } \\
\text { employees) }\end{array}$ \\
\\
\\
Method 1 \\
\end{tabular}} & \multirow[b]{2}{*}{$\begin{array}{c}\text { Compen- } \\
\text { sation } \\
\text { (millions of } \\
\text { dollars) }\end{array}$} & \begin{tabular}{|c|} 
Tourism \\
compensation \\
(millions of \\
dollars)
\end{tabular} & \multirow{2}{*}{$\begin{array}{c}\text { Average } \\
\text { compen- } \\
\text { sation per } \\
\text { tourism } \\
\text { employee } \\
\text { (dollars) }{ }^{*} I\end{array}$} \\
\hline & & & & & Method 1 & \\
\hline Hotels and lodging places *2 & 1,661 & 0.80 & 1,329 & 32,615 & 26,092 & 19,636 \\
\hline Eating and drinking places *3 & 6,819 & 0.16 & 1,091 & 81,265 & 13,002 & 11,917 \\
\hline Railroads and related services & 243 & 0.04 & 10 & 14,727 & 589 & 60,605 \\
\hline $\begin{array}{l}\text { Local and suburban transit and interurban highw ay passenger } \\
\text { transportation, except taxicabs * } 4\end{array}$ & 416 & 0.21 & 87 & 13,635 & 2,863 & 32,776 \\
\hline Water transportation & 100 & 0.14 & 14 & 4,650 & 651 & 46,500 \\
\hline Automotive rental and leasing, $w$ ithout drivers & 178 & 0.54 & 96 & 3,733 & 2,016 & 20,972 \\
\hline Arrangement of passenger transportation ${ }^{*} 6$ & 191 & 0.22 & 43 & 5,037 & 1,122 & 26,372 \\
\hline $\begin{array}{l}\text { Miscellaneous amusement and recreation services (except membership } \\
\text { sports and recreation clubs); racing including track operation; marinas; and } \\
\text { libraries and museums, art galleries, and botanical and zoological gardens }\end{array}$ & 633 & 0.18 & 114 & 10,973 & 1,975 & 17,335 \\
\hline Membership sports and recreation clubs & 297 & 0.31 & 92 & 5,348 & 1,658 & 18,007 \\
\hline $\begin{array}{l}\text { Motion picture theaters; dance studios, schools, and halls; theatrical } \\
\text { producers (except motion pictures), bands, orchestras, and entertainers }\end{array}$ & 282 & 0.17 & 48 & 6,042 & 1,027 & 21,426 \\
\hline Professional sports clubs and promoters & 46 & 0.13 & 6 & 3,716 & 483 & 80,783 \\
\hline
\end{tabular}

Source: Table 9, p17, "U.S. Travel and Tourism Satellite Accounts for 1992", Sumiye Okubo and Mark A. Planting, Survey of Current Business July 1998. Bureau of Economic Analysis, Reproduced with the Permission obtained by the author

Original notes: *1. Average compensation per tourism employee $w$ as calculated as the arithmetic mean of the average compensation per tourism employee for methods 1,2 and 3 .

*2. Self-employment for SIC 70 (Hotels and lodging) for 1992 is estimated at 56,000. (Source: Derived from Bureau of Labor Statistics, Current Population Survey, 1992.)

*3. Self employment for SIC 58 (Eating and drinking places) for 1992 is estimated at 490,000. (Source: Derived from Bureau of Labor Statistics, Current Population Survey, 1992.) )

*4. Employment for this category includes 206,000 State and local government "transit" employees. (Source: Table estimate for compensation.

*5. Self employment for SIC 41 for 1992 is estimated at 54,000, all of which is assumed to occur in SIC 4120 (Taxicabs). (Source: Derived from Bureau of Labor Statistics, Current Population Survey, 1992.)

*6. Self-employment for SIC 47 for 1992 is estimated at 27,000, all of which is assumed to occur in SIC 4720 (Arrangement of Passenger Transportation).

*7.-Employment and Payrolls of State and Local Governments by Type of Government and Function: October 1992, 1992 Census of Governments, Compendium of Public Employment). Compensation for the State and local government "transit" employees is estimated at $\$ 9,804,000,000$, which is added to the national income and product account

NOTE-See the section "Methodological Overview" for a discussion of the three methods. Sources: Bureau of Labor Statistics, U. S. Department of Labor, Employment and Wage Annual Averages, 1992;Bureau of the Census, U. S. Department of Commerce, 1992 Census of Governments, Compendium of Public Employment; and Bureau of Labor Statistics, U. S. Department of Labor, Current Population Survey, 1992.

Table 9. Tourism Employment and Compensation of Employees, 1992 (shortened version for display) 
As the base data for TSA are derived from those of the I-O, TSA data carries over some, if not all, of the same characteristic of the data in the I-O table.

- Employment does not distinguish a full and a part time employee. Either would be counted as one employee.

- Compensation of employees includes not only the direct wages and salaries but also supplementary welfares such as social security (national retirement funding in the U.S.), fringe benefits, employer contribution to retirement fund.

- All data are shown in annual basis

Now we look into components of the Table 9.

\subsubsection{Total employment (Unit: Thousands of employees)}

These are the data which you obtain from public offices which compiles labor-related statistics. In the U.S., it is the Bureau of Labor Statistics which estimates average monthly employment by industry at very detailed (four-digit SIC (Standard Industrial Code) level: currently SIC was changed to NAICS (North American Industrial Classification System)) level, and Bureau of Economic Analysis also makes estimates at detailed (two-digit SIC level: currently SIC was changed to NAICS) level. Total employments are basically quoting relevant data from appropriate labor statistics.

\subsubsection{Tourism industry ratio}

These are already calculated in the Table 8, so we simply copy the data into the same column formats. You may note that this ratio remains highly important in generating several TSA tables, which depends on the tourism industry ratios.

\subsubsection{Tourism employment (Unit: Thousands of employees)}

Now we know that tourism industry consists of many tourism-affiliated industrial sectors which cater to visitors in varying degrees. Counting all the employees working in those industrial sectors serving tourism demand will lead to overestimation of numbers of employment in the tourism industry. Thus we have to extract only the numbers of those whose employments are attributed to tourism demand. This is how the tourism industry ratios are utilized to filter out the tourism employment out of total employment in tourismrelated industrial sectors. To calculate the Tourism employment, take the Total employent (first column from left) to be multiplied by the corresponding Tourism industry ratio and the result will be Tourism employment to be shown at third column from left.

For example, for the Hotel and lodging places,

\begin{tabular}{|c|}
\hline 1,661 (thousands) $x$ \\
\hline otal employment \\
\hline
\end{tabular}

For the Eating and drinking places,

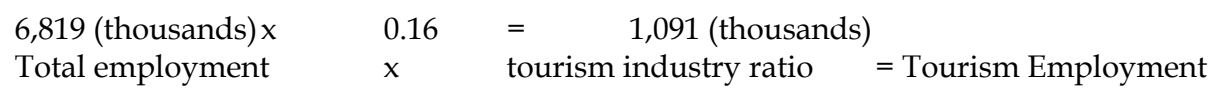


This calculation highlights the danger of overestimation of employment unless you have solid tourism industry ratio to filter out the non-tourism demands.

By continuing this calculation for all the other industrial sectors, you will have Tourism employment column completed.

\subsubsection{Compensation (Unit: Millions of dollars)}

This is the column that you will have difficulty in finding the source unless you have good basic knowledge on the structure and components of the I-O/SAM tables. Aggregate amounts of annual compensation per industrial sector are displayed in the I-O/SAM transaction table that is where you obtain these data. Recall that those figures include not only the direct wages and salaries but also the related fringe benefits. Again these figures are showing all the compensation for each sector and we have to repeat what we did with the calculations to tourism employment by utilizing Tourism industry ratio.

\subsubsection{Tourism compensation (Unit: Millions of dollars)}

Now we know that tourism industry consists of many tourism-affiliated industrial sectors which cater to visitors in varying degrees. Counting all the compensations paid to employees working in all industrial sectors serving tourism demand will lead to overestimation of compensations paid for those engaged in the tourism industry. Thus we have to extract only the compensation of those whose employments are attributed to tourism demand. This is how the tourism industry ratios are required to filter out the Tourism compensation out of Compensation in tourism-related industrial sectors. To calculate the Tourism compensation, take the (total) Compensation (the column approximately located in the middle) to be multiplied by the corresponding Tourism industry ratio (the second column from left) and the result will be Tourism compensation to be shown at second column from right.

For example, for the Hotel and lodging places,

$\begin{array}{llll}\$ 32,615 \text { million } & x & 0.80 & =\end{array} \$ 26,092$ million

(Total) Compensation $\quad \mathrm{x}$ tourism industry ratio $=$ Tourism Compensation

For the Eating and drinking places,
$\$ 81,265$ million
0.16
$=\$ 13,002$ million
(Total) Compensation $\quad \mathrm{x}$ tourism industry ratio $=$ Tourism Compensation

This calculation for Eating and drinking places highlights the danger of overestimation of employment unless you have solid tourism industry ratio to filter out the non-tourism demands.

By continuing this calculation for all the other industrial sectors, you will have Tourism employment column completed.

Average compensation per tourism employee (unit: dollars)

Having calculated number of employees and total amount of annual compensation paid to them, we can calculate one more interesting thing fairly easily by dividing Tourism compensation (millions of dollars) by tourism employment (thousands of employees). 
For example, for the Hotel and lodging places,

\$26,092 million $\quad \div \quad 1,329,000 \quad=\quad \$ 19,636$

(to say exactly, it may be $1,328,783$ )

Tourism Compensation $\div$ tourism employment $\quad=$ Tourism Compensation

(Annual total amount) (Annual average) (Annual amount per employee)

For the Eating and drinking places,

$\begin{array}{llll}\$ 13,002 \text { million } \quad \div \quad 1,091,000 & = & \$ 11,917\end{array}$

(to say exactly, it may be $1,091,046$ )

Tourism Compensation $\quad \div$ tourism employment $\quad=$ Tourism Compensation

(Annual total amount) (Annual average) (Annual amount per employee)

The data is based on data in 1992, so it may look outdated to your eyes if you try to put them in perspective with current data, but for example, there were higher paying occupations such as professional sports clubs and promoters.

$\begin{array}{llll}\$ 483 \text { million } \quad \div \quad 6,000 & = & \$ 80,783\end{array}$

(to say exactly, it may be 5,978 )

Tourism Compensation $\div$ tourism employment $\quad=$ Tourism Compensation

(Annual total amount) (Annual average) (Annual amount per employee)

By continuing this calculation for all the other industrial sectors, you will have Average compensation per tourism employee column completed.

\subsection{TSA overview}

Now, the overall components of the TSA by separate tables have been reviewed. With the minimum knowledge, you should be able to read through the existing TSA studies made by different governments in the world. While there may be some differences in details, thanks to the UNWTO's efforts to disseminate common guidelines, most of the structures of the TSA reports should look familiar to your eyes. Besides updated versions of US TTRA made by the same office in Bureau of Economic Analysis, there are several accessible TSA reports made by Canada, (http://unstats.un.org/unsd/EconStatKB/Attachment230.aspx ), and New Zealand (http://stats.govt.nz/browse_for_stats/industry_sectors/Tourism/tourismsatellite-account-info-releases.aspx ), to name a couple out of 60 nations.

\section{The latest development on TSA}

Since I wrote the similar but technically more detailed textbook on I-O/SAM and TSA (Hara 2008), there have been interesting developments in the area of TSA studies. With the leadership from UNWTO, application of TSA at sub-national level, or regional level has been advocated. Each region in a nation has different economic structures and therefore different importance of tourism as an industry. While the regional governments are eager to develop regional TSA, it will require intensive prime data collection on the part of regional governments. Both the existence of regional I-O data (not just a prorated miniature version of the national data, but I-O derived from actual regional transactions recorded) and availability of highly trained staff to deal with I-O and tourism specific TSA are the prerequisites for regional TSA, creating a high hurdle to develop ones. There are, however, examples of emerging Regional TSAs in some nations in the world. 
Because some regional governments are interested in quantifying the size of tourism as an industry for the purpose of receiving preferential funding allocations from the central government, the interests in regional TSA are expected to grow in the world. In the latest international conference ( $2^{\text {nd }}$ International Conference on the Measurement and Economic Analysis of Regional Tourism, Bilbao, Spain 2011) multiple papers on the regional measurement of tourism were presented by researchers from including but not limited to Spain, Ireland, Israel, Japan, Italy and USA.

http://www.inroutenetwork.org/conference/2011/

\subsection{Final comments on TSA}

TSA, as I explained, is a globally accepted accounting method to measure the tourism as an industry. Therefore, TSA cannot be "simulated" to be made as it is not a modelling technique. (Once the TSA is created in accordance with the global rules, it can be simulated in the same manner as Input-Output and its family model can). Since the TSA is based on the Input-Out framework, on which the System of National Accounts is also based, it is a deterministic accounting framework, which do not have stochastic component. Because the majority of the quantitative research studies in the current refereed journal in the tourism and hospitality fields are indeed scientific with inferential and stochastic components of data analysis, it is more challenging for researchers in TSA field to publish academic papers. Thus there appears to be a structural disconnect between academic researchers in tourism and the economists in the governmental tourism/economics offices, leaving many tourism and hospitality students stranded on one side of the valley.

With proper introduction to the founding structure of Input-Output, it is hoped that many more students will be interested in studying tourism as a serious and growing industry of the $21^{\text {st }}$ century.

\section{References}

Bureau of Economic Analysis. "Us International Travel Receipts and Payment by Countries 1999." edited by Bureau of Economic Analysis. Washington D. C.: U.S. Department of Commerce, 2000.

Hara, Tadayuki. Quantitative Tourism Industry Analysis: Elsevier, London, ISBN 978-07506-8499-6, 2008

Okubo, Sumiye, and Mark A. Planting. "U.S. Travel and Tourism Satellite Accounts for 1992." Survey of Current Business 78, no. 7 (1998): 8.

Organisation for Economic Co-operation and Development (OECD). "Tourism Satellite Accounts: A Conceptual Framework." In OECD meeting of National Accounts Experts, edited by World Tourism Organization. Paris, 1998.

Organisation for Economic Co-operation and Development. Measuring the Role of Tourism in Oecd Economies. Edited by OECD. Paris: OECD, 2000.

United Nations (U.N.). "Economic Statistics: National Accounts." edited by Economic and Social Council. New York: United Nations, 1999.

United Nations (U.N.). "Tourism Satellite Account: Recommended Methodological Framework." New York: Commission of the European Communities, Organisation for Economic Co-operation and Development, World Tourism Organisation, 2001. 
United Nations Statistics Division. 1993 System of National Accounts Statistics Division, 2007. Available from http://unstats.un.org/unsd/sna1993/introduction.asp.

WTO, World Tourism Organization. "Tourism Satellite Account, 3rd Draft/Review 1." Madrid: WTO, 1998.

WTO, World Tourism Organization. "General Guidelines for Developing the Tourism Satellite Account, Measuring Total Tourism Demand." Madrid: WTO, 2000.

World Tourism Organization (WTO). "The Tourism Satellite Account: Past, Present and Future Developments." In The Tourism Satellite Account as an ongoing process: past, present and future developments. Madrid, 2001.

World Tourism Organization. "Enzo Paci Papers on Measuring the Economic Significance of Tourism." In Introduction, edited by Volume 3. Madrid, 2003.

World Tourism Organization (WTO). "Adapting the National Tourism Satellite Account (Tsa) Project to Subnational Levels." edited by WTO Department of Statistics and Economic Measurement of Tourism. Madrid, 2005. 


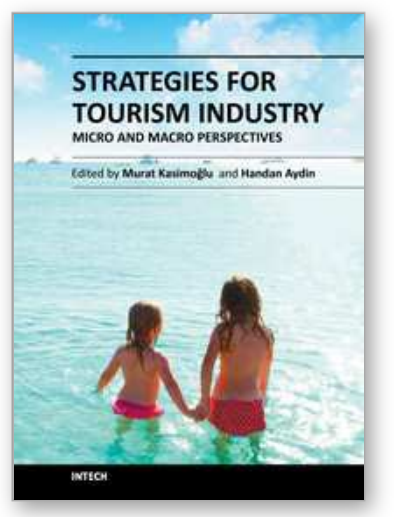

\author{
Strategies for Tourism Industry - Micro and Macro Perspectives \\ Edited by Dr. Murat Kasimoglu
}

ISBN 978-953-51-0566-4

Hard cover, 392 pages

Publisher InTech

Published online 20, April, 2012

Published in print edition April, 2012

Today, it is considered good business practice for tourism industries to support their micro and macro environment by means of strategic perspectives. This is necessary because we cannot contemplate companies existing without their environment. If companies do not involve themselves in such undertakings, they are in danger of isolating themselves from the shareholder. That, in turn, creates a problem for mobilizing new ideas and receiving feedback from their environment. In this respect, the contributions of academics from international level together with the private sector and business managers are eagerly awaited on topics and sub-topics within Strategies for Tourism Industry - Micro and Macro Perspectives.

\title{
How to reference
}

In order to correctly reference this scholarly work, feel free to copy and paste the following:

Tadayuki (Tad) Hara (2012). Introduction to Tourism Satellite Accounts, Strategies for Tourism Industry Micro and Macro Perspectives, Dr. Murat Kasimoglu (Ed.), ISBN: 978-953-51-0566-4, InTech, Available from: http://www.intechopen.com/books/strategies-for-tourism-industry-micro-and-macro-perspectives/tourismsatellite-accounts-as-a-de-jure-universal-tool-for-measurement-of-tourism-as-an-industry

\section{INTECH}

open science | open minds

\section{InTech Europe}

University Campus STeP Ri Slavka Krautzeka 83/A 51000 Rijeka, Croatia Phone: +385 (51) 770447

Fax: +385 (51) 686166 www.intechopen.com

\section{InTech China}

Unit 405, Office Block, Hotel Equatorial Shanghai No.65, Yan An Road (West), Shanghai, 200040, China 中国上海市延安西路65号上海国际贵都大饭店办公楼 405 单元 Phone: +86-21-62489820

Fax: +86-21-62489821 
(C) 2012 The Author(s). Licensee IntechOpen. This is an open access article distributed under the terms of the Creative Commons Attribution 3.0 License, which permits unrestricted use, distribution, and reproduction in any medium, provided the original work is properly cited. 